\title{
Characteristics of a Debris Flow Disaster and Its Mitigation Countermeasures in Zechawa Gully, Jiuzhaigou Valley, China
}

\author{
Xing-Long Gong ${ }^{1,2,3,+}{ }^{+}$Kun-Ting Chen ${ }^{1,+}{ }^{+}$, Xiao-Qing Chen ${ }^{1,2,3, *}$, Yong You ${ }^{1}$, \\ Jian-Gang Chen ${ }^{1,2}$, Wan-Yu Zhao ${ }^{1}$ and Jie Lang ${ }^{4}$ \\ 1 Key Laboratory of Mountain Hazards and Earth Surface Processes, Institute of Mountain Hazards and \\ Environment, Chinese Academy of Sciences, Chengdu 610041, China; gongxinglong@imde.ac.cn (X.-L.G.); \\ kuntingchen@imde.ac.cn (K.-T.C.); yyong@imde.ac.cn (Y.Y.); chenjg@imde.ac.cn (J.-G.C.); \\ wyzhao@imde.ac.cn (W.-Y.Z.) \\ 2 CAS Center for Excellence in Tibetan Plateau Earth Sciences, Beijing 100101, China \\ 3 University of Chinese Academy of Sciences, Beijing 100049, China \\ 4 Jiuzhai Valley National Park Administration Bureau, Sichuan 623402, China; jielang157698955@163.com \\ * Correspondence: xqchen@imde.ac.cn; Tel.: +86-028-6671-3416 \\ + These authors contributed equally to this work.
}

Received: 5 March 2020; Accepted: 26 April 2020; Published: 28 April 2020

\begin{abstract}
On 8 August 2017, an Ms 7.0 earthquake struck Jiuzhaigou Valley, triggering abundant landslides and providing a huge source of material for potential debris flows. After the earthquake debris flows were triggered by heavy rainfall, causing traffic disruption and serious property losses. This study aims to describe the debris flow events in Zechawa Gully, calculate the peak discharges of the debris flows, characterize the debris flow disasters, propose mitigation countermeasures to control these disasters and analyse the effectiveness of countermeasures that were implemented in May 2019. The results showed the following: (1) The frequency of the debris flows in Zechawa Gully with small- and medium-scale will increase due to the influence of the Ms 7.0 Jiuzhaigou earthquake. (2) An accurate debris flow peak discharge can be obtained by comparing the calculated results of four different methods. (3) The failure of a check dam in the channel had an amplification effect on the peak discharge, resulting in a destructive debris flow event on 4 August 2016. Due to the disaster risk posed by dam failure, both blocking and deposit stopping measures should be adopted for debris flow mitigation. (4) Optimized engineering countermeasures with blocking and deposit stopping measures were proposed and implemented in May 2019 based on the debris flow disaster characteristics of Zechawa Gully, and the reconstructed engineering projects were effective in controlling a post-earthquake debris flow disaster on 21 June 2019.
\end{abstract}

Keywords: debris flow; Zechawa Gully; mitigation countermeasures; Jiuzhaigou Valley

\section{Introduction}

A debris flow-a very to extremely rapid surging flow of saturated debris in a steep channel-is a widespread hazardous phenomenon in mountainous areas [1-3]. Because of their characteristics of high flow velocities, high impact forces and long run-out distances, debris flows pose a great threat to the safety of people, can cause catastrophic damage to infrastructure elements (such as roads and houses), and can even block rivers, leading to fatalities and property damage downstream [4-10]. In recent years, post-earthquake debris flow hazards have been widely investigated due to their long activity duration, high occurrence frequency and catastrophic damage [11-14]. Numerous studies have focused on rainfall thresholds and sediment supply to characterize the occurrence of post-earthquake 
debris flows. In the areas affected by the 1999 Chi-Chi earthquake and the 2008 Wenchuan earthquake, the thresholds for rainfall triggering post-earthquake debris flows were analysed, and it was recognized that the rainfall threshold in periods shortly after the earthquakes was markedly lower than that before the earthquake and gradually recovered over time [14-20]. In fact, a devastating earthquake generates a large sediment supply in the form of co-seismic collapses and landslides and changes the grain size of the material and the watershed permeability characteristics, thereby indirectly reducing the debris flow-triggering rainfall thresholds $[18,21]$. Because earthquakes tend to produce abundant loose material, if sufficient rainfall occurs soon after an earthquake, a catastrophic debris flow can be triggered. For example, influenced by the Wenchuan earthquake on 12 May 2008, a catastrophic debris flow event was triggered on 14 August 2010 in Hongchun Gully, claiming the lives of 32 people [8]. Similarly, five debris flow events were triggered in Wenjia Gully in the three rainy seasons after the Wenchuan earthquake, including a giant debris flow event on 13 August $2010[9,13]$.

As an effective way to mitigate debris flow hazards, engineering countermeasures have attracted widespread attention [22-33], and the mitigation of debris flows is usually carried out by stabilizing, blocking, drainage and deposit stopping measures [11,23]. Check dams, which act to stabilize the bed, consolidate hillslopes, decrease the slope, and retain and control the transport of sediment, are commonly used engineering structures for controlling debris flows and can generally be divided into solid-body dams and open dams $[25,28,29]$. Because solid-body dams are associated with many drawbacks, such as the erosion of the dam foundation and changes in the hillslope-to-channel connectivity [26,27], open dams are more efficient at controlling debris flows [28,29]. After the Wenchuan earthquake, to protect people's lives and property and ensure smooth traffic, a large number of debris flow engineering structures, especially check dams, were built. However, due to the insufficient realization on the characteristics and formation mechanisms of post-earthquake debris flows, many newly-built engineering structures have failed to mitigate debris flows and have instead caused catastrophic damage. For example, due to the failure of check dams in Sanyanyu Valley on 8 August 2010, more than 200 buildings were damaged, and approximately 1700 people died [34]. Similarly, during the " 8.13 " Wenjiagou debris flow event, engineering structures failed, causing seven deaths and the burial of more than 497 houses $[9,35]$. Therefore, further research should be carried out to propose appropriate mitigation countermeasures for post-earthquake debris flows.

Recently, an Ms 7.0 earthquake struck Jiuzhaigou Valley on 8 August 2017, triggering abundant landslides and providing a vast source of material for debris flows. Due to the influence of heavy rainfall, post-earthquake debris flows were triggered in Jiuzhaigou Valley and heavily damaged infrastructure elements, such as pedestrian walkways and scenic roads, causing traffic disruption and serious property losses [36-38]. It is necessary to evaluate the characteristics of post-earthquake debris flows in Jiuzhaigou Valley, and to propose appropriate mitigation countermeasures to avoid catastrophic events, but only a few studies related to post-earthquake debris flow mitigation in this area have been published to date. In this paper, Zechawa Gully is taken as a case study to characterize a debris flow disaster and then discuss mitigation countermeasures. To improve the accuracy of parameter calculation, four different methods were used to calculate the debris flow peak discharge and quantify the debris flow magnitude. According to the survey and analysis, the destructive debris flow event in 2016 was caused by a dam breach. After the Ms 7.0 Jiuzhaigou earthquake on 8 August 2017, abundant loose solid material was available for debris flow activity, and at least one post-earthquake debris flow occurred in September 2017. The risk of dam breaches led to the implementation of engineering countermeasures with blocking and deposit stopping measures. Such works were finished on May 2019. On 21 June 2019, a post-earthquake debris flow was triggered by heavy rainfall, and the engineering countermeasures played a useful role in controlling the debris flow disaster even though the debris flow magnitude was greater than the design standard of the reconstruction engineering projects. 


\section{Background}

\subsection{Formation Conditions of the Zechawa Gully Debris Flow}

Zechawa Gully, with gully mouth coordinates of $103^{\circ} 55^{\prime} 22.8^{\prime \prime} \mathrm{E}, 33^{\circ} 08^{\prime} 34.8^{\prime \prime} \mathrm{N}$, is located in Jiuzhaigou Valley, Sichuan Province, China, and lies approximately $13.9 \mathrm{~km}$ from a scenic entrance (Figure 1a,b). The outlet of the Zechawa Gully debris flow coincides with the location of the only scenic road from Nuorilang Waterfall to Long Lake (Figure 1c). The study area is the transition zone from the Qinghai-Tibet Plateau to the Sichuan Basin and belongs to the peripheral mountainous area of the Sichuan Basin. The watershed covers an area of $1.96 \mathrm{~km}^{2}$ and features five tributaries; the main channel is $2.57 \mathrm{~km}$ long and has a $61.1 \%$ longitudinal slope. The elevation difference of Zechawa Gully is approximately $1601 \mathrm{~m}$, with a maximum elevation of $4040 \mathrm{~m}$ in the southwest of the watershed and a minimum elevation of $2439 \mathrm{~m}$ at the gully mouth near the scenic road. The topography of Zechawa Gully is steep, with $86.9 \%$ of the total area of the watershed having a slope exceeding $25^{\circ}$. The flow path of debris flow along Zechawa Gully can be divided into a formation zone, transport zone and deposition zone (Table 1). The formation zone is located in the upper reaches of Zechawa Gully (elevation above $3620 \mathrm{~m}$ ), with an area of $0.26 \mathrm{~km}^{2}$ and a channel length of $470 \mathrm{~m}$. The transport zone is situated in the middle reaches, with the elevations ranging from $3620 \mathrm{~m}$ to $2600 \mathrm{~m}$. The area of the transport zone is approximately $1.47 \mathrm{~km}^{2}$, and the channel length is approximately $1530 \mathrm{~m}$. The deposition zone, with an area of $0.23 \mathrm{~km}^{2}$ and a channel length of approximately $570 \mathrm{~m}$, is located in the area below an elevation of $2600 \mathrm{~m}$.
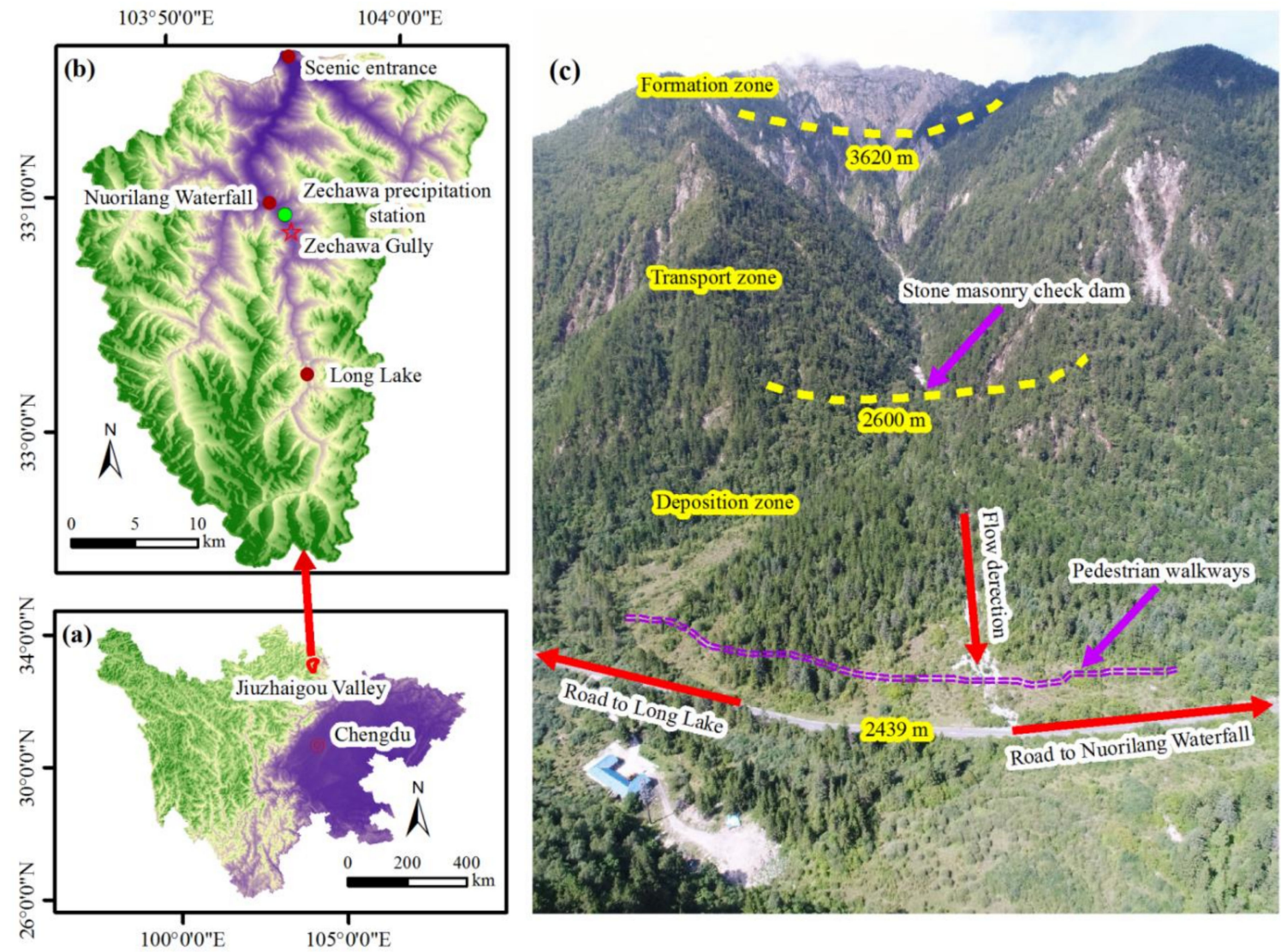

Figure 1. Location of Zechawa Gully and its full view. (a) Location of Jiuzhaigou Valley in Sichuan Province; (b) Location of Zechawa Gully in Jiuzhaigou Valley; (c) The full view of Zechawa Gully. The flow direction of the debris flow is perpendicular to the pedestrian walkways and the scenic road (from Nuorilang Waterfall to Long Lake). 
Table 1. Zone division of Zechawa Gully.

\begin{tabular}{|c|c|c|c|}
\hline Zone Division & Formation Zone & Transport Zone & Deposition Zone \\
\hline Elevation $(\mathrm{m})$ & $4040-3620$ & $3620-2600$ & $2600-2439$ \\
\hline Average gully gradient (\%o) & 708 & 415 & 244 \\
\hline Gully length (m) & 470 & 1530 & 570 \\
\hline Gully characteristics & $\begin{array}{l}\text { Steep slope }\left(>50^{\circ}\right) \text {, bare } \\
\text { bedrock with severe frost } \\
\text { weathering, low vegetation } \\
\text { coverage and abundant } \\
\text { collapsed regions }\end{array}$ & $\begin{array}{c}\text { Steep slopes, a large } \\
\text { number of landslides } \\
\text { and high abundance of } \\
\text { debris flow sediments on } \\
\text { the gully bed }\end{array}$ & $\begin{array}{c}\text { Gentle topography } \\
\text { with no collapses or } \\
\text { landslides }\end{array}$ \\
\hline
\end{tabular}

Compared with the characteristics of the formation zone and transport zone, the topography of the deposition zone is gentle, with no collapses and landslides, and debris flow material tends to be deposited in this area, forming a large debris flow fan. Zechawa Gully is generally a " $v$ "-shaped channel with the characteristics of a narrow gully bed, steep lateral slopes and a high longitudinal slope, providing favourable topographic conditions for the formation of debris flows.

The study area is located in the Songpan-Ganzi Block, and the outcropping strata are mainly Quaternary and Mesozoic (Figure 2a). The lithology consists mainly of limestone and slate with a small amount of sandstone, which were intensely deformed by folding and thrusting during the Late Triassic and Early Jurassic [39,40]. In addition, since the Quaternary, the geological tectonic movement in this area has been intense due to the influence of the Tazang fault (the eastern part of the East Kunlun Fault Zone), Minjiang fault and Huya fault [41-45] (Figure 2b). Historically, seismicity has occurred on the Minjiang fault and Huya fault, including the 1960 Zhangla Ms 6.7 earthquake, the 1973 Huanglong Ms 6.5 earthquake, and the 1976 Songpan-Pingwu earthquake swarm (Ms = 7.2, 6.7, and 7.2). A recent earthquake was the Jiuzhaigou 7.0 earthquake, which occurred on 8 August 2017 on the north-western extension of the Huya fault; the rupture was dominated by left-lateral strike-slip motion [41,46-48]. On the whole, seismicity is frequent in the study area due to the geological conditions of the region, resulting in the fracture of the rock mass in the study area and triggering abundant collapses and landslides, which provide a rich source of loose material for incorporation into debris flows.

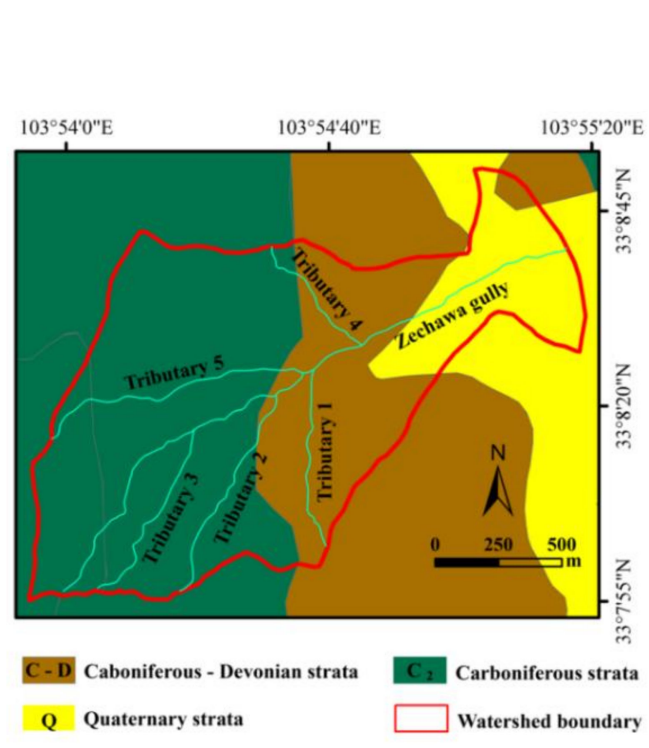

(a)

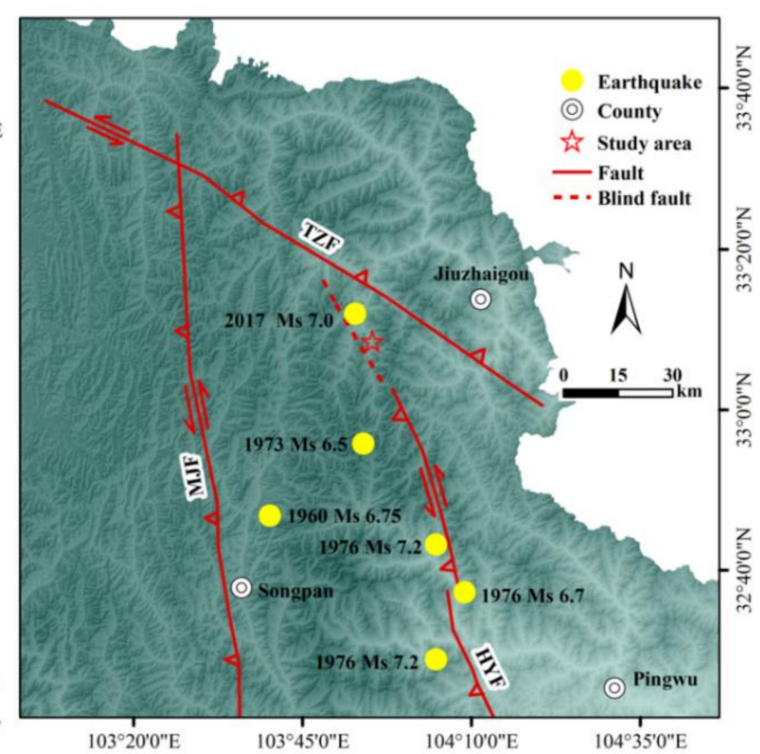

(b)

Figure 2. Study area maps. (a) Geologic map of the study area; (b) Topographic map of the Tazang fault (TZF), the Minjiang fault (MJF), the Huya fault (HYF) and the blind extension of the HYF (modified from Zhao et al. [41]). 
The study area features a plateau cold temperate-subarctic monsoon climate. Due to the blocking effect of the Longmen Mountains to the southeast of the study area, most of the warm and humid air currents from the Pacific Ocean stay to the east of the Longmen Mountains. Therefore, the rainfall in Jiuzhaigou Valley west of the Longmen Mountains is relatively low, and the annual average precipitation is only $761.8 \mathrm{~mm}$. The impact of cold air and high-pressure cold air currents from Mongolia in the winter is greatly weakened by the blocking of the Qinling Mountains to the north of the study area, causing this region to exhibit a mild climate, moderate precipitation and an annual average temperature of $7.3^{\circ} \mathrm{C}$ [49]. There are more than 150 rainfall days annually in the study area, and the rainfall is concentrated mainly in May to September in the form of rainstorms. According to the rainfall data from the Jiuzhaigou Administration Bureau, the maximum rainfall over $24 \mathrm{~h}$ in Jiuzhaigou Valley is greater than $50 \mathrm{~mm}$, and the precipitation increases with increasing elevation. The lowest average annual precipitation, at $696.6 \mathrm{~mm}$, is found at the outlet of Jiuzhaigou Valley at an elevation of $1996 \mathrm{~m}$. The highest annual average precipitation, at $957.5 \mathrm{~mm}$, is found at Long Lake at an elevation of $3100 \mathrm{~m}$. The snowpack period is from October to April, and the largest recorded snowpack depth exceeded $150 \mathrm{~mm}$. The rainfall conditions of the study area are characterized by concentrated heavy rainfall, which is favourable for the formation of debris flows.

\subsection{Description of the Debris Flow Events in Zechawa Gully}

Due to the steep topography, adequate supply of loose material and intense precipitation in the study area, debris flows are active in Zechawa Gully. The earliest recorded debris flow event occurred in August 2006 and buried pedestrian walkways. In July 2008, another debris flow occurred again and blocked the scenic road. To prevent debris flows from causing further damage to the downstream pedestrian walkways and the only scenic road and to ensure the safety of residents and tourists in scenic areas, engineering countermeasures were taken in 2009. These countermeasures were designed to resist a debris flow with a 20-year return period. One stone masonry check dam $34.7 \mathrm{~m}$ long and $8 \mathrm{~m}$ high was constructed at the end of the transport zone of Zechawa Gully in 2009 (Figure 1c), and one auxiliary dam was constructed close to the stone masonry check dam. The stone masonry check dam was designed to be able to trap a volume of $2.24 \times 10^{4} \mathrm{~m}^{3}$ of debris flow material [50].

On 4 August 2016, another destructive debris flow was triggered in Zechawa Gully. The rainfall data from the Zechawa precipitation station ( $103^{\circ} 55^{\prime} 04.8^{\prime \prime} \mathrm{E}, 33^{\circ} 09^{\prime} 18.0^{\prime \prime} \mathrm{N}$, Figure $\left.1 \mathrm{~b}\right)$ showed that the preceeding rainfall that accumulated from 26 July 2016 to 3 August 2016 was only $8.8 \mathrm{~mm}$, and the intraday rainfall was $6.7 \mathrm{~mm}$ on 4 August 2016. During this debris flow event, large amounts of sediment were trapped in front of the stone masonry check dam, resulting in a deposited thickness of $7 \mathrm{~m}$ and width of $30 \mathrm{~m}$, and the length of the debris flow deposit behind the check dam was $44 \mathrm{~m}$ according to field measurements (Figure 3a). As sediments deposited, a breach formed in the check dam. Ultimately, the average width of the breach was $20.5 \mathrm{~m}$, and the residual height of the check dam was $6 \mathrm{~m}$ (Figure $3 \mathrm{~b}$ ). The large kinetic energy of strong flow waves formed by the breach of check dam caused a high erosion of the downstream gully bed. During the movement of the debris flow material, the trees on both sides of the channel were impacted, leaving noticeable mud marks (Figure 3c). According to the field investigation, the total volume of the debris flow material transported downstream the failed check dam was approximately $1.39 \times 10^{4} \mathrm{~m}^{3}$. Some of the material was deposited on the debris flow fan with a deposit area of $0.77 \times 10^{4} \mathrm{~m}^{2}$, a thickness of $0.8-1.5 \mathrm{~m}$ and a volume of $0.89 \times 10^{4} \mathrm{~m}^{3}$. Additional material with a volume of $0.5 \times 10^{4} \mathrm{~m}^{3}$ was transported to the scenic road. During this debris flow event, the pedestrian walkways were buried again, and the only scenic road from Nuorilang Waterfall to Long Lake was blocked, causing traffic disruption and serious property loss $[37,51]$. 
The upstream of the check dam
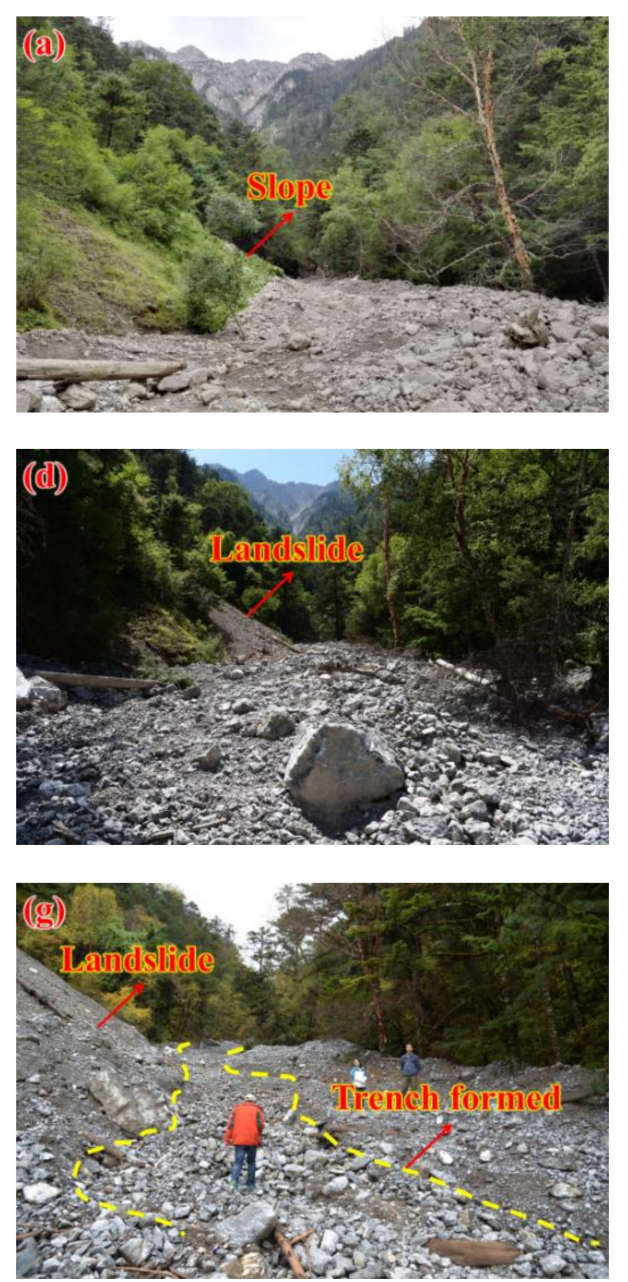

The breach of the check dam
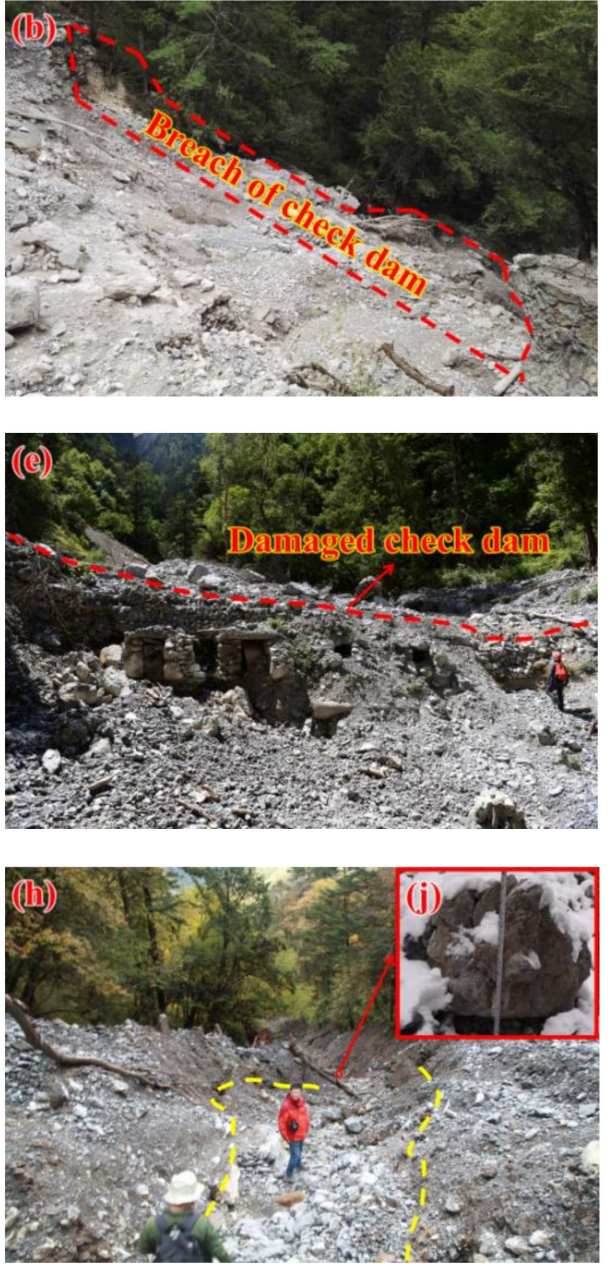

The downstream of the check dam
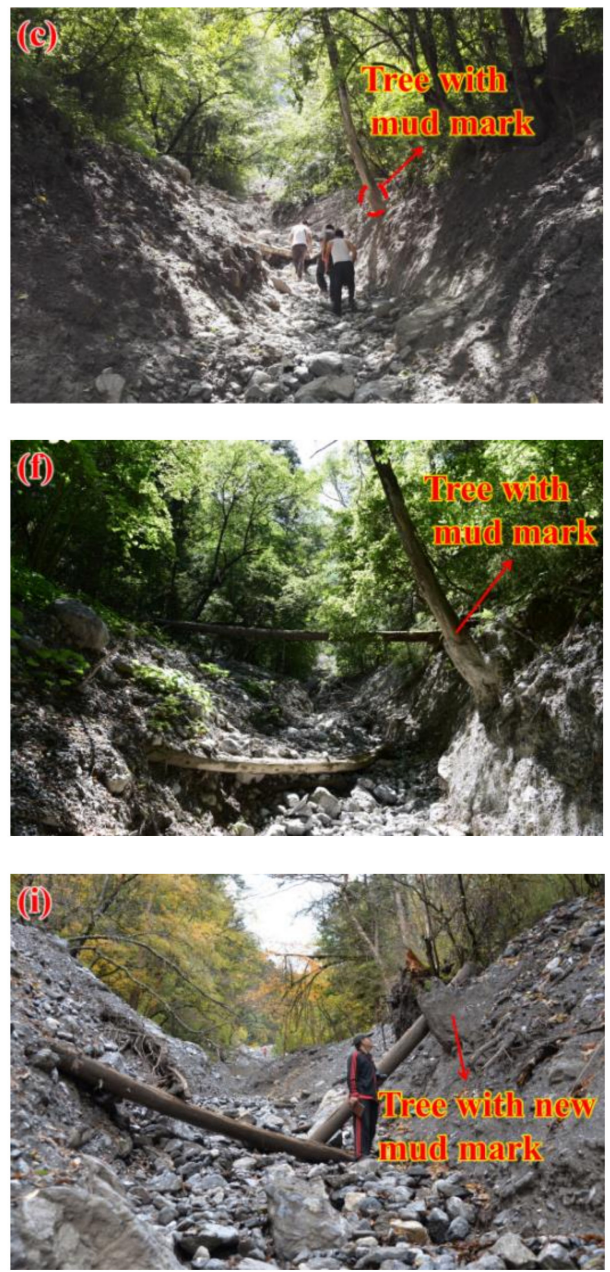

Figure 3. Images of Zechawa Gully debris flow in different periods: (a)-(c) 6 August 2016, (d)-(f) 16 August 2017, (g)-(i) 23 October 2017; (j) large boulder transported by the debris flow that occurred in September 2017. 
On 8 August 2017, the Ms 7.0 Jiuzhaigou earthquake struck the study area, and abundant landslides were triggered (Figure 3d), providing a vast source of material for debris flows. However, this earthquake had little influence on the breach shape of the check dam (Figure 3e) or the downstream topography of the check dam (Figure 3f). Subsequently, heavy rainfall occurred in the study area in September 2017. The rainfall data from Zechawa precipitation station showed that the total rainfall in September 2017 was $243.2 \mathrm{~mm}$, accounting for approximately 32\% of the total annual rainfall (Figure 4). Affected by the heavy rainfall in September 2017, a debris flow occurred, and the topography changed significantly. At the upstream check dam, the erosion caused by the debris flow was intense. An erosional trench approximately $1.0 \mathrm{~m}$ in depth was formed upstream of the dam (Figure $3 \mathrm{~g}$ ), and the breach in the dam was detectably deepened due to the erosion induced by the debris flow (Figure $3 \mathrm{~h}$ ). Due to the very high transport capacity of the debris flow, a large boulder with a long-axis length of $1.3 \mathrm{~m}$, an intermediate-axis length of $1.1 \mathrm{~m}$ and a short-axis length of $0.7 \mathrm{~m}$ was transported to a point $20 \mathrm{~m}$ downstream of the check dam, and this boulder was composed of masonry (Figure 3j). Downstream of the check dam, the debris flow material was deposited in the channel. Additionally, trees on both sides of the channel were broken due to the very large destructive power of the debris flow, and new mud marks were left on the trees (Figure 3i). Fortunately, pedestrian walkways and scenic roads were not destroyed again. To reduce the disaster risk of the post-earthquake debris flow in Zechawa Gully, one concrete check dam, one concrete auxiliary dam and one concrete retaining wall were constructed in May 2019.

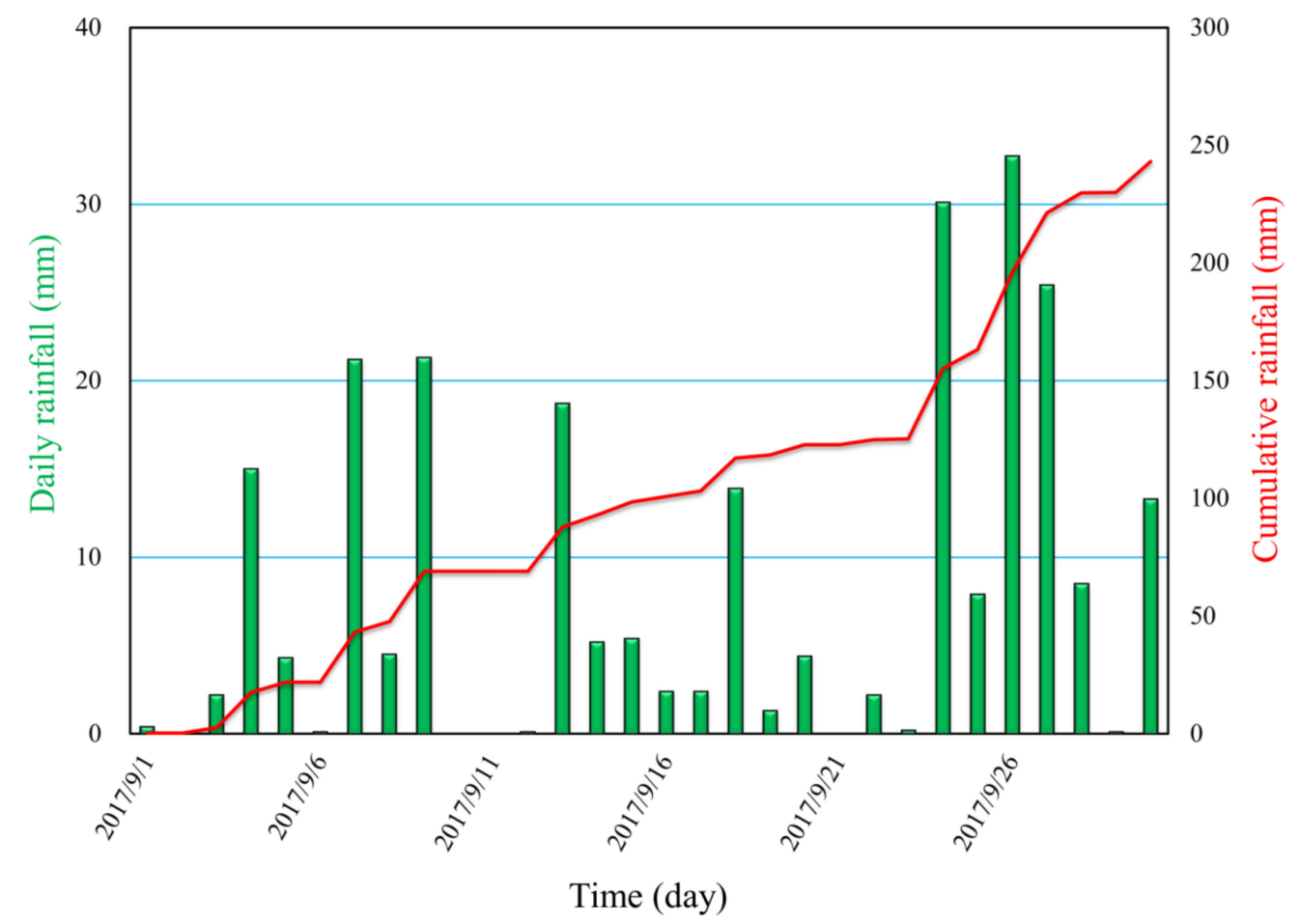

Figure 4. Rainfall distribution in September 2017 recorded by the Zechawa precipitation station.

A rainfall event started at 20:00 on 20 June 2019 and ended at approximately 08:00 on 21 June 2019 in Jiuzhaigou Valley. According to reports from patrol personnel, a post-earthquake debris flow was triggered by this storm at approximately 03:00 on 21 June 2019, and the rainfall data from the Zechawa precipitation station showed that the accumulated rainfall from 21:00 on 20 June 2019 to 02:00 on 21 June 2019 was $18.1 \mathrm{~mm}$. According to the field investigation, the total volume of debris flow material was approximately $2.3 \times 10^{4} \mathrm{~m}^{3}$. The debris flow material volume trapped by the concrete check dam was approximately $0.48 \times 10^{4} \mathrm{~m}^{3}$ (Figure 5). Some of the other debris flow material was trapped behind the retaining wall with a deposit area of $0.3 \times 10^{4} \mathrm{~m}^{2}$, a maximum deposit thickness of 
$4 \mathrm{~m}$ at the middle of the retaining wall and a deposit volume of $0.66 \times 10^{4} \mathrm{~m}^{3}$ (Figure 6). The middle of the retaining wall was partially damaged, resulting in a breach with a width of $8.5 \mathrm{~m}$, due to the high impact force of the debris flow. This breach allowed a portion of the debris flow material with a volume of $1.16 \times 10^{4} \mathrm{~m}^{3}$ to be transported to the debris flow fan and scenic road (Figure 7). The material volume deposited on the fan was approximately $0.93 \times 10^{4} \mathrm{~m}^{3}$ with a deposit area of $0.62 \times 10^{4} \mathrm{~m}^{2}$ and an average deposit thickness of $1.5 \mathrm{~m}$. The volume of the material blocking the scenic road was approximately $0.23 \times 10^{4} \mathrm{~m}^{3}$, with a deposit length of $180 \mathrm{~m}$ and an average deposit thickness of $1.8 \mathrm{~m}$.

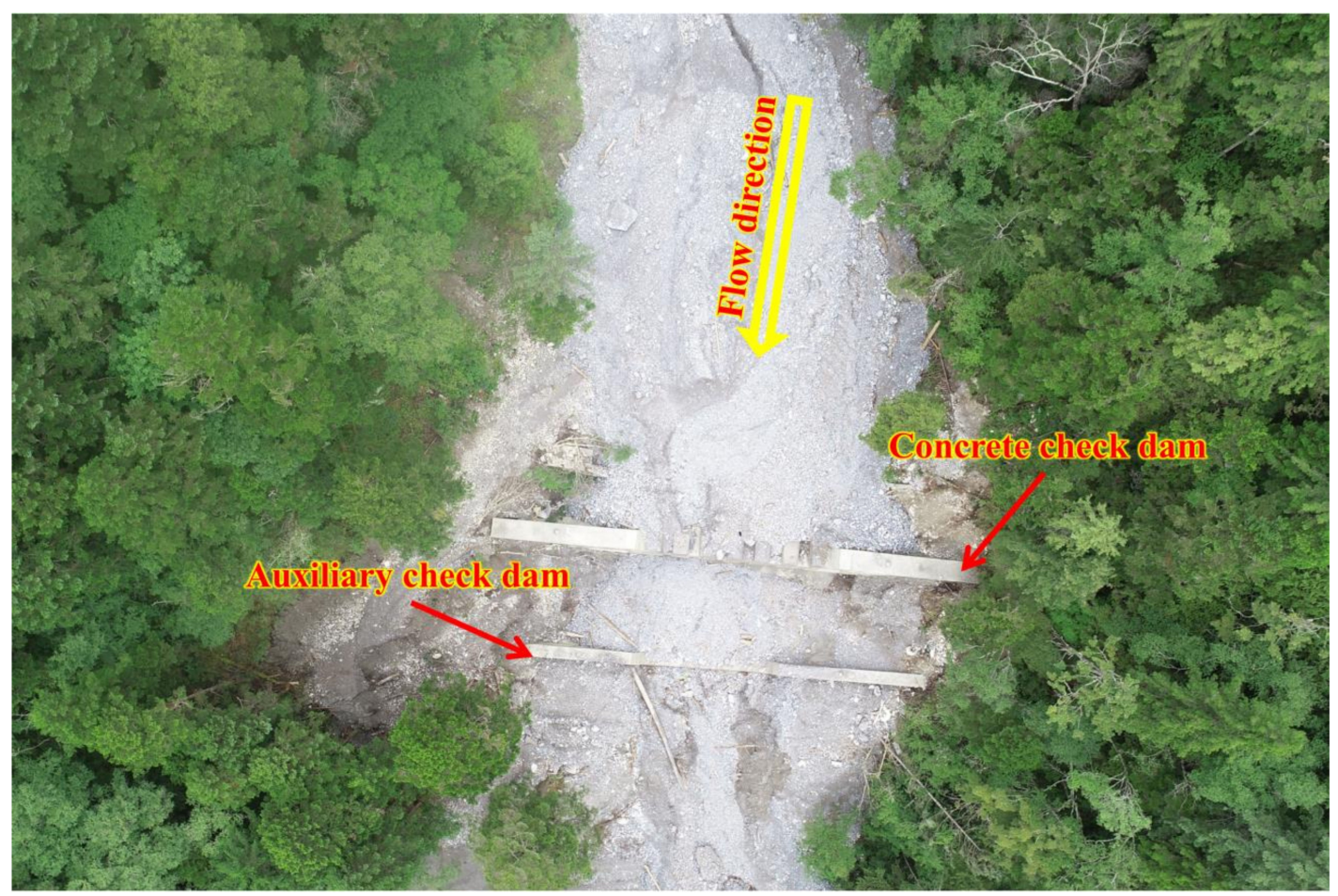

Figure 5. Overview of the reconstructed check dams in Zechawa Gully (taken on 25 June 2019).

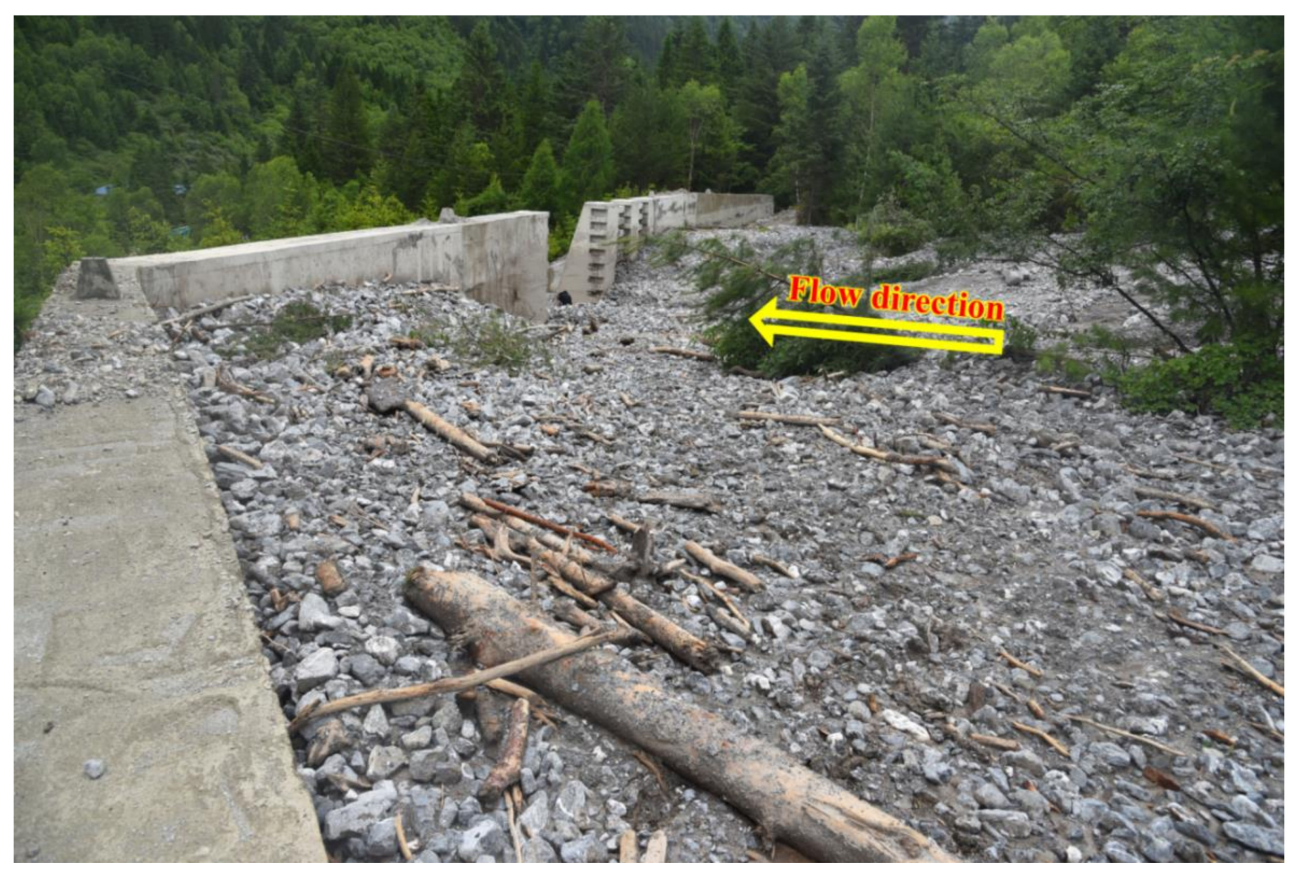

Figure 6. Overview of the reconstructed retaining wall in Zechawa Gully (taken on 23 June 2019). 


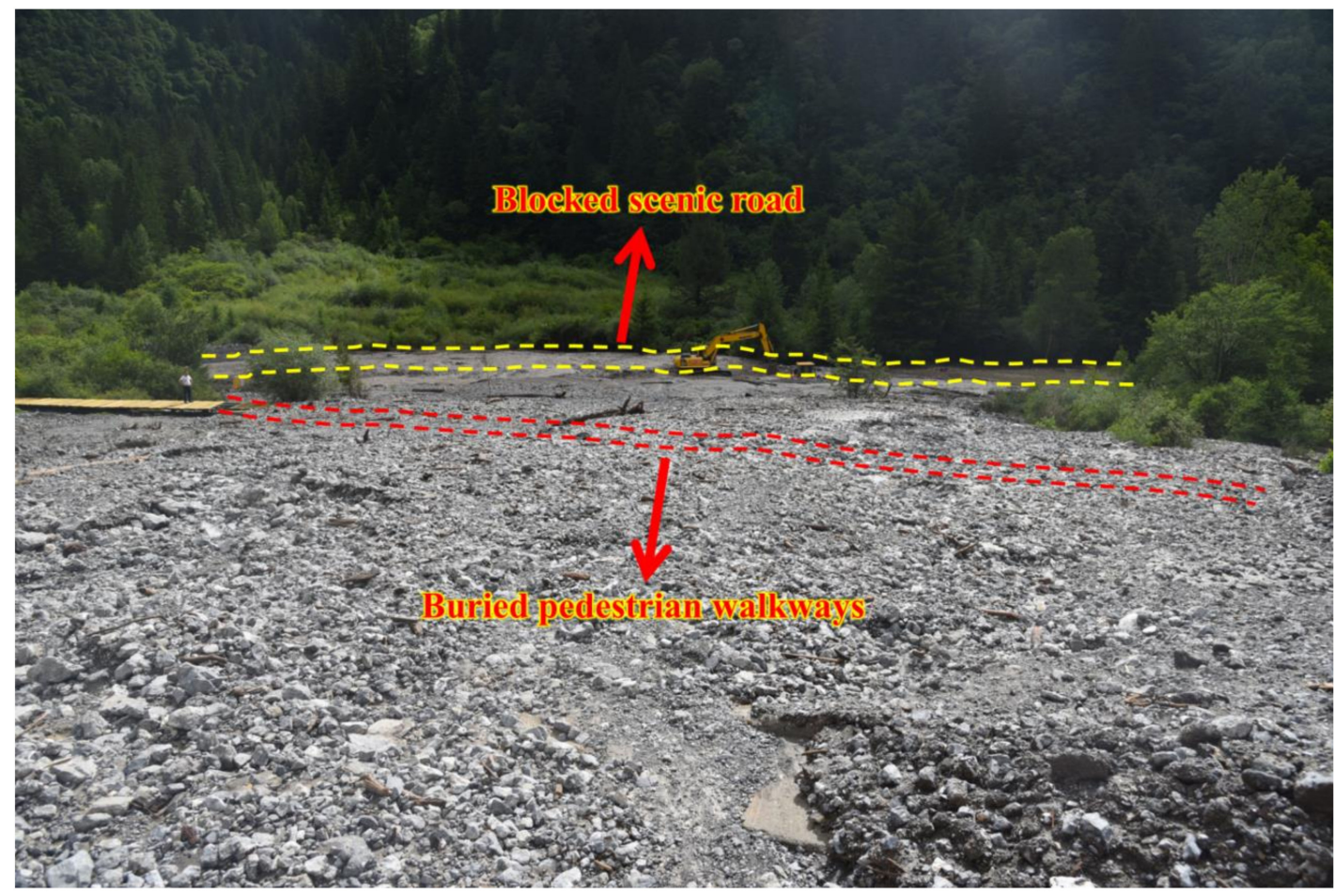

Figure 7. The debris flow that occurred on 21 June 2019 buried pedestrian walkways and blocked the scenic road (taken on 22 June 2019).

\section{Calculation of the Debris Flow Peak Discharge}

In the mountainous areas of China, due to the lack of observation data, the rain-flood method and cross-section survey method have been widely used to calculate the debris flow peak discharge [52]. Under the assumption that the occurrence frequencies of rainstorms, floods and debris flows are the same, the rain-flood method is widely employed to calculate the debris flow peak discharge under different occurrence frequencies $[53,54]$. The cross-section survey method calculates the peak discharge of a debris flow that has occurred based on the mud mark and cross-sectional morphology of the channel $[7,55]$.

For the debris flow event that occurred on 4 August 2016, two obvious typical cross-sections downstream of the stone masonry check dam are available for the calculation of the debris flow discharge through the cross-section survey method. Moreover, the pedestrian walkways were buried, and the scenic roads were blocked, and the stone masonry check dam in the channel was broken during this debris flow event. According to previous research, the amplification effect caused by dam breakage can contribute to debris flow damage in downstream towns $[9,56]$. Therefore, to characterize the relationship between dam failure and the occurrence of the debris flow on 4 August 2016, the dam-breaking peak discharges were estimated through the dam-breaking calculation method.

During the debris flow event that occurred in September 2017, the cross-section survey method was unavailable due to the lack of an available cross-section. A coarse boulder with dimensions of $1.3 \mathrm{~m}, 1.1 \mathrm{~m}$ and $0.7 \mathrm{~m}$ was transported $20 \mathrm{~m}$ downstream of the check dam by the debris flow in September 2017. According to previous studies, the largest transported particle reflects the maximum kinetic energy of flooding in mountain streams, and the maximum particle size parameters are widely used to reconstruct the velocity, depth and peak discharge of floods [57]. Thus, in this study, based on the assumption that the rainstorm, flood and debris flow frequencies were the same, the maximum particle size parameters were used to calculate the flood peak discharge, and the peak discharge of the debris flow in September 2017 was then estimated by using the methodology proposed by Lanzoni [58] according to the calculated flood peak discharge. 


\subsection{Rain-Flood Method}

The debris flow peak discharges under different occurrence frequencies are computed by Ref. [54]:

$$
\begin{gathered}
Q_{d f}=D_{d f}\left(1+\psi_{d f}\right) Q_{f} \\
\psi_{d f}=\left(\gamma_{d f}-\gamma_{w}\right) /\left(\gamma_{s}-\gamma_{d f}\right)
\end{gathered}
$$

where $D_{d f}$ is the blockage coefficient, whose value varies with the degree of blockage, namely, very serious blockage $\left(D_{d f}=3.0-2.6\right)$, serious blockage $\left(D_{d f}=2.5-2.0\right)$, normal blockage $\left(D_{d f}=1.9-1.5\right)$ and minor blockage $\left(D_{d f}=1.4-1.1\right) ; \psi_{d f}$ is the amplification coefficient of the debris flow peak discharge; $\gamma_{d f}$ is the density of the debris flow $\left(\mathrm{t} / \mathrm{m}^{3}\right) ; \gamma_{w}$ is the density of water $\left(\mathrm{t} / \mathrm{m}^{3}\right)$, usually taken as $1.00 \mathrm{t} / \mathrm{m}^{3}$; $\gamma_{s}$ is the density of the solid material $\left(\mathrm{t} / \mathrm{m}^{3}\right)$, usually taken as $2.65 \mathrm{t} / \mathrm{m}^{3}$; and $Q_{f}$ is the flood peak discharge under different return periods $\left(\mathrm{m}^{3} / \mathrm{s}\right)$, which is calculated by:

$$
Q_{f}=0.278 \varphi \frac{S}{t^{n}} F
$$

where $\varphi$ is the runoff coefficient of the flood peak, which is related to the convergence of runoff; $S$ is the rainfall intensity $(\mathrm{mm}) ; t$ is the runoff confluence time of the rainstorm $(\mathrm{h}) ; n$ is the attenuation index of the rainstorm; and $F$ is the watershed area $\left(\mathrm{m}^{2}\right)$. Here, $\varphi, S, t$ and $n$ are calculated by the following empirical equations:

$$
\begin{gathered}
\varphi=1-1.1 \frac{\eta}{S} t_{0}{ }^{n} \\
S=H_{1} K_{1} \\
t=t_{0} \varphi^{-\frac{1}{4-n}} \\
n=1+1.285\left(\lg \frac{H_{1} K_{1}}{H_{6} K_{6}}\right)
\end{gathered}
$$

where $H_{1}$ and $H_{6}$ are the 1-hour average rainfall and 6-hour average rainfall, respectively (mm), which are obtained from "The Rainstorm and Flood Calculation Manual of Medium and Small Basins in Sichuan Province" (published in 2010, with rainfall data from 1978 to 2004); $K_{1}$ and $K_{6}$ are the modulus coefficients corresponding to $H_{1}$ and $H_{6}$ under different return periods, respectively, which can be obtained from a Pearson type III distribution table; $\eta$ is the runoff yield parameter, which reflects the average infiltration intensity $(\mathrm{mm} / \mathrm{h}) ; t_{0}$ is the runoff confluence time of the rainstorm when $\varphi$ equals 1 , which can be calculated by:

$$
\begin{gathered}
\eta=3.6 K_{P} F^{-0.19} \\
t_{0}=\left[\frac{0.383}{m S^{1 / 4} / \theta}\right]^{\frac{4}{4-n}}
\end{gathered}
$$

where $K_{p}$ is the modulus coefficient when the variation coefficient is equal to 0.23 , which is obtained from the Pearson type III distribution table; $m$ is the runoff confluence parameter; and $\theta$ is the watershed characteristic parameter, which is obtained from:

$$
\begin{gathered}
m=0.221 \theta^{0.204} \\
\theta=\frac{L}{J^{1 / 3} F^{1 / 4}}
\end{gathered}
$$

where $L$ is the main channel length and $J$ is the longitudinal slope of the channel.

\subsection{Cross-Section Survey Method}

Because natural channels have irregular channel bottoms, information on the channel roughness is not easy to obtain and measure. Therefore, an empirical formulation (Manning formula) was 
developed for turbulent flows in rough channels. It can be applied to calculate the discharge for fully rough turbulent flows and water flows. Although it is an empirical relationship, it has been found to be reasonably reliable $[59,60]$. Thus, the Manning formula was employed to obtain debris flow peak discharge when computing by the cross-section survey method. Based on the mud marks and cross-section morphology of the channel, the debris flow peak discharge $Q_{d f}\left(\mathrm{~m}^{3} / \mathrm{s}\right)$ can be obtained by Ref. [54]:

$$
Q_{d f}=A_{d f} V_{d f}
$$

where $A_{d f}$ is the area of the cross-section $\left(\mathrm{m}^{2}\right)$, and $V_{d f}$ is the average velocity of the debris flow $(\mathrm{m} / \mathrm{s})$, which can be calculated by:

$$
V_{d f}=\frac{1}{n_{d f}} R_{d f}^{2 / 3} I_{d f}^{1 / 2}
$$

where $n_{d f}$ is the roughness coefficient of the debris flow gully, $R_{d f}$ is the hydraulic radius of the debris flow $(\mathrm{m})$, and $I_{d f}$ is the longitudinal slope gradient of the channel bed $(\mathrm{m} / \mathrm{m})$.

\subsection{Dam-Breaking Calculation Method}

Considering the scarcity of observational data in this study, three commonly used semi-empirical methods are employed to obtain the dam-breaking peak discharge during the debris flow event on 4 August 2016. The semi-empirical method of the Ministry of Water Resources of the People's Republic of China (MWR) [61] estimates the debris flow peak discharge $Q_{d f}$ through:

$$
\begin{gathered}
Q_{d f}=\frac{8}{27} \sqrt{g}\left[B_{0} h_{0} / B_{m}\right]^{0.28} B_{m}\left(h_{0}-h_{d}\right)^{1.22} \\
Q_{d f}=\frac{8}{27} \sqrt{g}\left(\frac{B_{0}}{B_{m}}\right)^{0.4}\left(\frac{h_{0}+10 h_{d}}{h_{0}}\right)^{0.3} B_{m}\left(h_{0}-h_{d}\right)^{1.5}
\end{gathered}
$$

where $g$ is acceleration due to gravity $\left(9.8 \mathrm{~m}^{2} / \mathrm{s}\right) ; B_{0}$ is the debris flow width before breakage $(\mathrm{m}) ; h_{0}$ is the debris flow depth before breakage $(\mathrm{m}) ; B_{m}$ is the breach width $(\mathrm{m})$, and $h_{d}$ is the residual height of the dam.

The semi-empirical method of Dai and Wang [62] calculates the debris flow peak discharge $Q_{d f}$ by:

$$
Q_{d f}=0.27 \sqrt{g}\left(L_{b} / B_{0}\right)^{1 / 10}\left(B_{0} / B_{m}\right)^{1 / 3} B_{m}\left(h_{0}-\kappa h_{d}\right)^{3 / 2}
$$

where $L_{b}$ is the deposit length of the debris flow material behind the check dam (m); $\mathrm{k}$ is the influence factor that accounts for residual height, which is obtained by:

$$
\kappa=\left\{\begin{array}{l}
1.4\left(B_{m} h_{d} / B_{0} h_{0}\right)^{1 / 3}, B_{m} h_{d} / B_{0} h_{0}<0.3 \\
0.92, B_{m} h_{d} / B_{0} h_{0}>0.3
\end{array}\right.
$$

\subsection{Maximum Boulder Size Method}

Based on the particle size parameters of the maximum-sized boulder, the debris flow peak discharge can be obtained through Ref. [58]:

$$
\begin{gathered}
Q_{d f}=\frac{1}{1-C} Q_{f} \\
C=\frac{\rho_{f} \tan \beta}{\left(\rho_{s}-\rho_{f}\right)\left(\tan \phi_{d f}-\tan \beta\right)}
\end{gathered}
$$

where $C$ is the transported sediment concentration; $\rho_{f}$ is the fluid density $\left(\mathrm{kg} / \mathrm{m}^{3}\right) ; \rho_{s}$ is the sediment density; $\beta$ is the bed slope angle (degrees), and the value of $\beta$ is usually between $15^{\circ}$ to $25^{\circ}$ when using 
Equation (19) [63]; $\varphi_{d f}$ is the quasi-static friction angle (degrees); and $Q_{f}$ is the flood peak discharge $\left(\mathrm{m}^{3} / \mathrm{s}\right)$, which was estimated by the methods of Schoklitsch, Helley, Williams and Clarke.

\subsubsection{Method of Schoklitsch}

This method estimates the flood peak discharge $Q_{f}\left(\mathrm{~m}^{3} / \mathrm{s}\right)$ by computing the unit width flux by Ref. [64,65]:

$$
\begin{gathered}
q_{f}=\frac{0.0194 d_{I}}{(\tan \beta)^{4 / 3}} \\
Q_{f}=q_{f} * B_{f}
\end{gathered}
$$

where $q_{f}$ is the unit width flux; $d_{I}$ is the diameter of the boulder intermediate axis $(\mathrm{m})$, and $B_{f}$ is the channel width (m).

\subsubsection{Method of Helley}

This method computes the "bed velocity" for incipient motion (overturning) by equating the turning moments for fluid, drag, and lift with the resisting moment of the submerged particle weight. The critical velocity $V_{f}$ (bed velocity) can be calculated by Ref. [66]:

$$
\begin{gathered}
V_{f}=3.276\left[\frac{\left(\rho_{b} / 1000-1\right) d_{L}\left(d s+d_{I}\right)^{2} M R_{L}}{\left(C^{\prime}{ }_{D} d_{S} d_{L} M R_{D}+0.178 d_{I} d_{L} M R_{L}\right)}\right]^{0.5} \\
M R_{L}=d_{I} \cos \alpha / 4+\sqrt{\frac{3}{16} d_{S}{ }^{2}} \sin \alpha \\
M R_{D}=0.1 d_{S} \cos \alpha+\sqrt{\frac{3}{16} S_{2}^{d}} \cos \alpha-d_{I} \sin \alpha / 4
\end{gathered}
$$

where $\rho_{b}$ is the maximum boulder density $\left(\mathrm{kg} / \mathrm{m}^{3}\right) ; d_{L}$ is the diameter of the boulder long axis $(\mathrm{m}) ; d_{S}$ is the diameter of the boulder short axis (m); $C^{\prime}{ }_{D}$ is the drag coefficient; $M R_{D}$ and $M R_{L}$ are the drag turning arm and lift turning arm, respectively; and $\alpha$ is the original imbrication angle of the deposited boulder. During the calculation process, Equation (22) uses English units of feet, and the units of critical velocity calculated by Equation (22) need to be converted into metres per second.

The critical velocity $V_{f}$ calculated by Equation (22) needs to be converted to the average velocity $V_{\text {avg }}$ [57]:

$$
V_{\mathrm{avg}}=1.2 V_{f}
$$

The flood peak discharge $Q_{f}$ can then be calculated as the product of the average velocity, mean depth and channel width by:

$$
Q_{f}=V_{a v g} h_{f} B_{f}
$$

where $h_{f}$ is the mean flood depth $(\mathrm{m})$. Given that the channel width was much larger than the mean depth of flooding, the hydraulic radius obtained by the Manning formula can estimate the average depth; thus, $h_{f}$ was obtained by the Manning formula:

$$
h_{f}=\left(\frac{V_{a v g} n_{f}}{\sqrt{\tan \beta}}\right)^{1.5}
$$

where $n_{f}$ is the roughness coefficient of a mountain stream.

\subsubsection{Method of Williams}

This approach calculates either the bed shear stress or the stream power needed to entrain the boulder. First, the intermediate axis diameter of the largest boulder $d_{I}$ is obtained through field 
investigation, and then the empirical relationship between the unit stream power $w$, bed shear stress $\tau$, average velocity $V_{\text {avg }}$ and $d_{I}$ is established by Ref. [67]:

$$
\begin{gathered}
w=0.079 d_{I}^{1.3} \\
\tau=0.17 d_{I} \\
V_{a v g}=0.065 d_{I}^{0.5}
\end{gathered}
$$

$V_{a v g}, h_{f}$ and $Q_{f}$ based on the shear stress can be determined by Equations (30)-(32), respectively:

$$
\begin{aligned}
& h_{f}=\frac{\tau}{\rho_{b} g \tan \beta} \\
& Q_{f}=\frac{w * B_{f}}{\rho_{b} g \tan \beta}
\end{aligned}
$$

$V_{a v g}$ and $h_{f}$ based on the stream power can be obtained by:

$$
\begin{gathered}
V_{a v g}=\frac{Q_{f} \rho_{b} g \tan \beta}{B_{f} \tau} \\
h_{f}=\frac{w}{\rho_{b} g \tan \beta * 0.065 \sqrt{d_{I}}}
\end{gathered}
$$

The value of $Q_{f}$ in Equation (33) is obtained by Equation (32); then, $Q_{f}$ based on the stream power can be obtained by inserting the calculated values of $V_{a v g}$ and $h_{f}$ from Equations (33) and (34), respectively, into Equation (26).

\subsubsection{Method of Clarke}

This method assumes that the critical force (i.e., the minimum force needed to move the boulder) is equal to the resisting force and that the critical force is equal to the sum of the lift force and drag force. The critical velocity $V_{f}$ (bed velocity) required to carry the maximum-sized boulder is solved by the following formula [68]:

$$
V_{f}=\left\{2\left[\left(F_{D} / C_{D}\right) / \rho_{f}\right] / A_{B}\right\}^{0.5}
$$

where $C_{D}$ is the lift coefficient of the boulder, which is dependent on the shape of the largest boulder, with $C_{D}=1.18$ for a cubic boulder and 0.20 for a spherical boulder; $A_{B}$ is the cross-sectional area of the largest boulder; and $F_{D}$ is the drag force, which is obtained by:

$$
F_{D}=C_{D} F_{C} /\left(C_{L}+C_{D}\right)
$$

where $C_{L}$ is the lift drag coefficient, which is dependent on the shape of the largest boulder, with $C_{L}=0.178$ for a cubic boulder and 0.20 for a spherical boulder; and $F_{C}$ is the critical force, which is calculated by:

$$
\begin{gathered}
F_{C}=F_{R} \\
F_{R}=M_{B}\left[\left(\rho_{b}-\rho_{f}\right) / \rho_{b}\right] g(\mu \cos \beta-\sin \beta)
\end{gathered}
$$

where $\mu$ is the shape coefficient, which is dependent on the shape of the largest boulder, with $\mu=0.675$ for a cubic boulder and 0.225 for a spherical boulder; and $M_{B}$ is the boulder mass (kg). $M_{B}$ can be obtained for a cubic boulder and a spherical boulder by Equations (39) and (40), respectively:

$$
\begin{gathered}
M_{B}=\rho_{b} D^{3} \\
M_{B}=\rho_{b}\left[(\pi / 6) D^{3}\right]
\end{gathered}
$$


where $D$ is the nominal diameter of the boulder $(\mathrm{m})$, which is solved by:

$$
D=\left(d_{L} d_{I} d_{S}\right)^{0.33}
$$

The flood peak discharge $Q_{f}$ can be obtained by inserting the calculated value of $V_{f}$ into Equations (25)-(27).

\section{Results}

\subsection{The Calculated Debris Flow Peak Discharge in 2016}

With the data collected during the field investigation, the peak discharge of the debris flow that occurred on 4 August 2016 was estimated by the cross-section survey method and dam-breaking calculation method. Table 2 shows the calculation results for the debris flow peak discharge. The permissible debris flow peak discharges at the two typical mud mark cross-sections estimated by the cross-section survey method were $33.29 \mathrm{~m}^{3} / \mathrm{s}$ and $36.69 \mathrm{~m}^{3} / \mathrm{s}$. The values of $A_{d f}, R_{d f}$ and $I_{d f}$ were obtained through field investigation. The roughness coefficient of the debris flow gully $\left(n_{d f}\right)$ is related to the properties of the debris flow fluid and channel characteristics, and the value in this case is 0.1 according to a field survey [54].

Table 2. Calculation results of the debris flow peak discharge by using the cross-section survey method and dam-breaking calculation method.

\begin{tabular}{cccccccc}
\hline \multicolumn{2}{c}{ Methods } & \multicolumn{7}{c}{ Parameters } \\
\hline & & $A_{d f}\left(\mathrm{~m}^{2}\right)$ & $R_{d f}(\mathrm{~m})$ & $I_{d f}$ & $V_{d f}(\mathrm{~m} / \mathrm{s})$ & $n_{d f}$ & $Q_{d f}\left(\mathrm{~m}^{3} / \mathrm{s}\right)$ \\
\multicolumn{2}{c}{ cross-section survey method } & 6.45 & 0.75 & 0.391 & 5.16 & 0.1 & 33.29 \\
& & 9.58 & 0.85 & 0.182 & 3.83 & 0.1 & 36.69 \\
\hline & & $B_{0}(\mathrm{~m})$ & $h_{0}(\mathrm{~m})$ & $B_{m}(\mathrm{~m})$ & $h_{d}(\mathrm{~m})$ & $L_{b}(\mathrm{~m})$ & $Q_{d f}\left(\mathrm{~m}^{3} / \mathrm{s}\right)$ \\
dam-breaking & Equation (14) & 30.0 & 7.0 & 20.5 & 6.0 & $/$ & 36.5 \\
calculation & Equation (15) & 30.0 & 7.0 & 20.5 & 6.0 & $/$ & 43.6 \\
method & Equation (16) & 30.0 & 7.0 & 20.5 & 6.0 & 44.0 & 36.8 \\
\hline
\end{tabular}

According to the calculation results in Table 2, the permissible maximum debris flow peak discharges resulting from the breach in the check dam varied from $36.5 \mathrm{~m}^{3} / \mathrm{s}$ to $43.6 \mathrm{~m}^{3} / \mathrm{s}$. The calculation result by Equation (14) was the lowest $\left(36.5 \mathrm{~m}^{3} / \mathrm{s}\right)$, and the calculation result by Equation (15) was the highest $\left(43.6 \mathrm{~m}^{3} / \mathrm{s}\right)$. The values of $B_{0}, h_{0}, B_{m}, h_{d}$, and $L_{b}$ were obtained by field investigation. Since the data inputs used in Equations (14)-(16) were the same, the differences among the results arose from the different combinations of data used for a given technique. The calculated values are reasonable and are similar to the debris flow peak discharge estimated by the cross-section survey method.

\subsection{The Calculated Debris Flow Peak Discharge in 2017}

With data collected during the field investigation, the peak discharge of the debris flow that occurred in September 2017 was calculated by the maximum boulder size method. Table 3 shows the calculation results. The calculated values of $Q_{f}$ vary from $0.58 \mathrm{~m}^{3} / \mathrm{s}$ to $6.05 \mathrm{~m}^{3} / \mathrm{s}$, and the calculated values of $Q_{d f}$ range from $1.76 \mathrm{~m}^{3} / \mathrm{s}$ and $18.33 \mathrm{~m}^{3} / \mathrm{s}$. The minimum permissible debris flow peak discharge of $1.76 \mathrm{~m}^{3} / \mathrm{s}$ is estimated through the method of Schoklitsch, and the maximum discharge of $18.33 \mathrm{~m}^{3} / \mathrm{s}$ is estimated through the method of Helley. $\rho_{f}$ is usually taken as $1150 \mathrm{~kg} / \mathrm{m}^{3}$ considering the turbidity of the flood waters [68]. $\rho_{s}$ is usually taken as $2650 \mathrm{~kg} / \mathrm{m}^{3}$. Owing to the absence of information, a value of $36.5^{\circ}$ was given for $\varphi_{d f}$ based on previous studies [58]. The values of $d_{L}, d_{I}, d_{S}$, $\rho_{b}, B_{f}, \beta$, and $\alpha$ were obtained through field investigation. The transported sediment concentration (C) is 0.67 by inserting the values of $\rho_{f}, \rho_{s}, \beta$ and $\varphi_{d f}$ into Equation (19). The roughness coefficient of a mountain stream $\left(n_{f}\right)$ is related to the channel characteristics, and a value of 0.05 was used here according to a field survey [69]. 
Table 3. Summary of the calculation results based on the maximum boulder size methods.

\begin{tabular}{ccccccc}
\hline & $d_{L}(\mathrm{~m})$ & 1.3 & $B_{f}(\mathrm{~m})$ & 6.5 & $\rho_{s}\left(\mathrm{~kg} / \mathrm{m}^{3}\right)$ & 2650 \\
Basic parameters & $d_{I}(\mathrm{~m})$ & 1.1 & $\beta$ (degrees) & 19 & $\varphi_{d f}($ degrees $)$ & 36.5 \\
& $d_{S}(\mathrm{~m})$ & 0.7 & $\alpha$ (degrees) & 6 & C & 0.67 \\
& $\rho_{b}\left(\mathrm{~kg} / \mathrm{m}^{3}\right)$ & 2250 & $n_{f}$ & 0.05 & & \\
\hline & & \multicolumn{5}{c}{ Parameters } \\
\hline Method & & $V_{a v g}(\mathrm{~m} / \mathbf{s})$ & $h_{f}(\mathbf{m})$ & $Q_{f}\left(\mathbf{m}^{3} / \mathbf{s}\right)$ & $Q_{d f}\left(\mathbf{m}^{3} / \mathbf{s}\right)$ \\
\hline Schoklitsch [64] & & $/$ & $/$ & 0.58 & 1.76 \\
Helley [66] & & 4.26 & 0.22 & 6.05 & 18.33 \\
Williams [67] & Shear stress & 2.16 & 0.03 & 0.61 & 1.85 \\
Clarke [68] & Stream power & 3.80 & 0.04 & 1.07 & 3.24 \\
\hline
\end{tabular}

\subsection{The Calculated Debris Flow Peak Discharge under Different Occurrence Frequencies}

According to the magnitude of the debris flow, hazard degree and importance of the protection object, mitigation countermeasures in Zechawa Gully were required to resist a debris flow with a return period of 20-50 years [70]. Thus, the debris flow peak discharges under 10-, 20- and 50-year return periods were computed, and the calculated results of related parameters are listed in Table 4. The possible debris flow peak discharges under 10-year, 20-year and 50-year return periods are $22.27 \mathrm{~m}^{3} / \mathrm{s}, 32.73 \mathrm{~m}^{3} / \mathrm{s}$ and $48.27 \mathrm{~m}^{3} / \mathrm{s}$ respectively. In the calculation sections, the values of $F, L$ and $J$ are different, resulting in different debris flow peak discharges estimated by the rain-flood method.

Table 4. Calculation results of the debris flow peak discharge by using the rain-flood method.

\begin{tabular}{|c|c|c|c|c|c|}
\hline \multirow{2}{*}{ Calculation Content } & \multirow{2}{*}{ Parameters } & \multirow{2}{*}{ Unit } & \multicolumn{3}{|c|}{ Return Periods } \\
\hline & & & 10-Year & 20-Year & 50-Year \\
\hline \multirow{14}{*}{ The flood peak discharge } & $\theta$ & $/ /$ & 2.14 & 2.14 & 2.14 \\
\hline & $m$ & / & 0.26 & 0.26 & 0.26 \\
\hline & $H_{1}$ & $\mathrm{~mm}$ & 15 & 15 & 15 \\
\hline & $H_{6}$ & $\mathrm{~mm}$ & 25 & 25 & 25 \\
\hline & $K_{1}$ & / & 1.72 & 2.10 & 2.58 \\
\hline & $K_{6}$ & / & 1.66 & 1.99 & 2.42 \\
\hline & $K_{P}$ & / & 1.31 & 1.42 & 1.56 \\
\hline & $S$ & $\mathrm{~mm}$ & 25.8 & 31.5 & 38.7 \\
\hline & $n$ & / & 0.73 & 0.74 & 0.8 \\
\hline & $\eta$ & $\mathrm{mm} / \mathrm{h}$ & 4.26 & 4.62 & 5.07 \\
\hline & $t_{0}$ & $\mathrm{~h}$ & 1.52 & 1.43 & 1.34 \\
\hline & $\varphi$ & / & 0.75 & 0.79 & 0.82 \\
\hline & $t$ & $\mathrm{~h}$ & 1.66 & 1.54 & 1.43 \\
\hline & $Q_{f}$ & $\mathrm{~m}^{3} / \mathrm{s}$ & 6.37 & 8.58 & 11.55 \\
\hline \multirow{4}{*}{ The debris flow peak discharge } & $\gamma_{d f}$ & $\mathrm{t} / \mathrm{m}^{3}$ & 1.8 & 1.85 & 1.9 \\
\hline & $D_{d f}$ & 1 & 1.8 & 1.85 & 1.9 \\
\hline & $Q_{d f}$ & $\mathrm{~m}^{3} / \mathrm{s}$ & 22.27 & 32.73 & 48.27 \\
\hline & $W_{d f}$ & $\mathrm{~m}^{3}$ & $0.88 \times 10^{4}$ & $1.30 \times 10^{4}$ & $1.91 \times 10^{4}$ \\
\hline
\end{tabular}

To better compare with the debris flow peak discharges calculated by the cross-section survey method, dam-breaking calculation method and maximum boulder size method, the calculation section located at the check dam site was selected to compute the debris flow peak discharges through the rain-flood method. The values of $F, L$ and $J$ were obtained from a topographic map with a scale of 1:5000. According to the results of the querying specification table and spot investigation, the average density of the debris flow was $1.8 \mathrm{t} / \mathrm{m}^{3}$. Under given conditions, the debris flow density is positively related to the debris flow peak discharge [54,71], thus the densities of the debris flows $\gamma_{d f}$ under the three return periods (10-year, 20-year and 50-year) were $1.8 \mathrm{t} / \mathrm{m}^{3}, 1.85 \mathrm{t} / \mathrm{m}^{3}$ and $1.9 \mathrm{t} / \mathrm{m}^{3}$, respectively. 
According to the site investigation, the blockage degree of the channel was normal, and the values of $D_{d f}$ were considered to be 1.8-1.9.

\section{Discussion}

\subsection{The Applicability and Limitations of the Calculated Debris Flow Peak Discharge}

The debris flow peak discharge is an important parameter for debris flow disaster prevention and risk assessment. As debris flows occur in remote mountain areas, it is difficult to measure the peak discharge and other parameters of debris flow under the conditions of severe weather and traffic delays. At present, the debris flow peak discharge is usually calculated by the rain-flood method and cross-section survey method based on certain assumptions, resulting in calculation results with low credibility. In this study, under certain assumptions, the peak discharge of debris flow was estimated by the rain-flood method, the cross-section survey method, the dam-breaking calculation method and the maximum boulder size method, and comparative analysis of the calculation results was conducted to obtain an accurate peak discharge. The limitations of the calculation results are explained as follows:

(1) Due to the complexity of debris flows and the measurement limitation, the values of relevant parameters are usually obtained by field surveys and querying the specifications. In this study, the roughness coefficient of the debris flow gully $\left(n_{d f}\right)$, the roughness coefficient of a mountain stream $\left(n_{f}\right)$, the density of debris flow $\left(\gamma_{d f}\right)$ and the blockage coefficient $\left(D_{d f}\right)$ were obtained through field investigations and querying specifications.

(2) Considering the complexity of the debris flow and the operability of the calculation method, it is necessary to make certain assumptions and simplifications to obtain the peak discharge of the debris flow in the calculation process. The rain-flood method assumes that the occurrence frequencies of rainstorms, floods and debris flows are the same and that the calculated flood peak discharge is completely converted into the peak discharge of the debris flow [54]. Under such assumptions, important parameters such as debris flow peak discharge and total volume of debris flow material under different occurrence frequencies can be obtained, which provide important references for the design of engineering countermeasures. In addition, the breach in the check dam was idealized as a trapezoidal shape, and the average width of the breach was taken as the calculated value of $B_{m}$ in the dam-breaking calculation.

(3) Four methods were used to estimate the peak discharge of the debris flow based on the maximum particle size parameters (Table 3), and the related issues in the calculation are as follows: Both Clarke and Helley solved for the critical velocity required to move the largest boulder, obtained the flow depth through the Manning formula, and finally calculated the peak discharge. Differences in the critical velocity result in differences in the flow depth and peak discharge. The method of Clarke idealizes the largest boulder as either cubic or spherical for the shape-dependent parameters, and the calculated velocities are averaged to provide the critical velocity. By setting the critical force $F_{C}=0$, the downward gravitational component is balanced by the gravity-induced friction, and the extreme use condition of this method can be obtained. The limit bed slope angle $(\beta)$ is equal to $34.1^{\circ}$ for a cubic boulder and $12.7^{\circ}$ for a spherical boulder when using the Clarke method; therefore, a spherical boulder is easier to move than the cubic boulder under the same conditions. According to the field investigation, $\beta$ is equal to $19^{\circ}$, which exceeds the limit bed slope angle for a spherical boulder. Therefore, the selected boulder in this study was considered a cubic boulder, resulting in a calculated critical velocity that is higher than the actual value. Compared with the method of Clarke, the method of Helley neglects the bed slope, ignoring the downstream gravitational component. Generally, the bed slope of a stream is small; even for a stream with a channel longitudinal slope of $10 \%$, the downstream gravitational component is negligibly small compared to the fluid drag and lift, so this component can be ignored [57]. However, the bed slope is $19^{\circ}$ in this study, and neglecting the gravitational component results in a calculated critical velocity that is much higher than the actual value, ultimately resulting in 
a higher calculated peak discharge. The methods of Schoklitsch and Williams estimate the peak discharge by establishing an empirical correlation based on boulder size parameters without considering the influence of the boulder shape on the calculation results. In addition, the values of $w, \tau$ and $V_{\text {avg }}$ in the method of Williams represent the lowest values, and the actual values are higher than the calculated value.

(4) In summary, certain assumptions and simplifications were made in the calculation process, causing the peak discharge of the debris flow calculated by a single method to exhibit low accuracy. Thus, multiple methods should be used to comprehensively obtain the peak discharge, further quantifying the scale of debris flow disasters. It is worth noting that the method for calculating the debris flow peak discharge proposed in this study is mainly based on the specifications in China, especially the selection of some parameters. When calculating the debris flow peak discharge in other countries, local specifications should be considered.

\subsection{The Scales of the Debris Flow Disasters in 2016 and 2017}

To identify the disaster characteristics and the occurrences of debris flow events, the peak discharges of the debris flows occurring on 4 August 2016 and in September 2017 were estimated based on field investigations, and the calculation results were compared with the debris flow peak discharges under different occurrence frequencies to quantify the scale of the debris flow disasters. The related explanations are as follows:

(1) The debris flow peak flow obtained by the cross-section survey method and dam-breaking calculation method are essentially the same and are generally equivalent to the peak discharge of the debris flow with a 20-year return period (Tables 2 and 4). In addition, the total volume of the debris flow material $W_{d f}$ is estimated by Ref. [54]:

$$
W_{d f}=0.264 Q_{d f} T_{d f}
$$

where $T_{d f}$ is the duration time of the debris flow (s), and its value is approximately $1500 \mathrm{~s}$ based on the reports of patrol personnel. The value of $Q_{d f}$ is the average calculation result through the cross-section survey method and dam-breaking calculation method, and its value is $37.38 \mathrm{~m}^{3} / \mathrm{s}$. The total volume of debris flow material from Equation (42) is $1.48 \times 10^{4} \mathrm{~m}^{3}$, which is consistent with the value of $1.39 \times 10^{4} \mathrm{~m}^{3}$ based on the field investigation. Thus, it is reasonable that the scale of the debris flow on 4 August 2016 is equivalent to that of a debris flow with a 20-year return period. Moreover, based on the study above, the debris flow peak discharges calculated by Equations (14)-(16) were similar to the values obtained by the cross-section survey method. Thus, we conclude that the debris flow peak discharge on 4 August 2016 was amplified by the failure of the check dam, causing widespread damage, and this aspect also explains why the magnitude of the debris flow on 4 August 2016 was large even though the accumulated rainfall and rainfall intensity were extremely low. Similarly, check dam failures have led to catastrophic disasters in other regions, such as the "8.13" Wenjiagou debris flow event [72] and the "8.8" Zhouqu debris flow event $[73,74]$.

(2) Based on the above analysis, the flood peak discharge estimated by the method of Helley is the largest, and is equivalent to that of a debris flow with a 10-year return period. Both of the peak discharges calculated by the methods of Clarke and Helley are larger than the actual value, while the value calculated by the method of Williams is smaller than the actual value. In addition, compared with the extensive destruction of the 2016 debris flow event with a 20-year return period, the destruction of the 2017 debris flow event was smaller, according to the field investigation. Therefore, it is reasonable that the magnitude of the debris flow in September 2017 was less than that of a debris flow with a 10-year return period.

(3) In the remote mountain areas of China, rainfall data are difficult to obtain, and the rainfall throughout a whole catchment usually cannot be recorded by precipitation stations due to the 
influence of terrain, resulting in inconsistencies between the triggering rainfall and the scale of debris flow disasters. Thus, the relationships between the occurrence of debris flow disasters and the triggering rainfall are not researched in this paper.

\subsection{Mitigation Countermeasures in Zechawa Gully}

More than $23 \times 10^{4} \mathrm{~m}^{3}$ of loose solid material was generated by the Ms 7.0 Jiuzhaigou earthquake and remains available as material for debris flows in Zechawa Gully in the near future [37,75]. Therefore, appropriate engineering countermeasures must be taken in a timely manner to mitigate post-earthquake debris flow disasters. According to the field investigation and calculation results above, the stone masonry check dam built in 2009 were broken, and the failure of the check dam amplified the debris flow peak discharge, resulting in a very large amount of damage during the debris flow event on 4 August 2016. Thus, the potential failure of a check dam should be fully taken into account during engineering design processes, and an integrated strategy including blocking measures and deposit stopping measures should be adopted for debris flow mitigation. On the one hand, the construction of deposit stopping structures (e.g., retaining walls) can increase the retention capacity of engineering structures; on the other hand, the debris flow material can be trapped by the deposit stopping structures even if the blocking structures (e.g., check dams) in the channel are damaged, thereby reducing the disaster risk downstream.

The engineering countermeasure taken in 2009 were designed to resist a debris flow with a 20-year return period but were damaged during the debris flow event in 2016. Considering the high-frequency and large-scale characteristics of post-earthquake debris flows, engineering countermeasures were designed to resist a debris flow with a 50-year return period after the Ms 7.0 Jiuzhaigou earthquake based on the scale, damage degree and threatened objects threatened by the subsequent debris flows. The total volume of debris flow material with a 50-year return period can be obtained by inserting the calculated value of $Q_{d f}$ into Equation (42), and the resulting value is $1.91 \times 10^{4} \mathrm{~m}^{3}$ (Table 4). Thus, the designed engineering structures are required to trap at least $1.91 \times 10^{4} \mathrm{~m}^{3}$ of debris flow material. In addition, the control principles of prevention projects should not only control the debris flow itself but also operate in harmony with the landscape and reduce the harm to landscape resources, as required in Jiuzhaigou Valley [76]. Under the guidance of these principles, in conjunction with the specific characteristics of the Zechawa debris flows, a concrete check dam and a concrete auxiliary dam were constructed in the channel, and a concrete retaining wall was constructed on the debris flow fan. The concrete check dam, $42.6 \mathrm{~m}$ long and $6 \mathrm{~m}$ high, was built close to but downstream of the broken stone masonry check dam in order to reduce the peak discharge, stabilize the gully bed, minimize scouring along the bottom and sides of the gully, and stabilize the debris flow material trapped behind the broken check dam. The downstream concrete auxiliary dam, $38.1 \mathrm{~m}$ long and $3 \mathrm{~m}$ high, was constructed close to the concrete check dam to protect the latter's foundation (Figure 5). Moreover, the reconstructed check dams were located somewhat upstream in the gully and were satisfactorily concealed. The retaining wall with a total length of $95.6 \mathrm{~m}$ was built $93 \mathrm{~m}$ away from the scenic road and is out of sight of tourists, and it can trap a volume of $2.27 \times 10^{4} \mathrm{~m}^{3}$ of debris flow materials (Figure 6). In May 2019, new control works (the reconstructed check dam and the retaining wall) were finished.

\subsection{Effectiveness of Mitigation Countermeasures and Evaluation of Debris Flow Impact Force}

On 21 June 2019, one post-earthquake debris flow was triggered by heavy rainfall, and a volume of $2.3 \times 10^{4} \mathrm{~m}^{3}$ of debris flow material was transported; this value was greater than the calculated total volume of debris flow material with a 50-year return period in Table 4 . A volume of $0.48 \times 10^{4} \mathrm{~m}^{3}$ of debris flow sediment was trapped by the concrete check dam (Figure 5), which contributed to stabilizing the gully bed and preventing entrainment of additional material. Moreover, a volume of approximately $0.66 \times 10^{4} \mathrm{~m}^{3}$ debris flow sediment was trapped by the retaining wall (Figure 6), and a portion of material with a volume of $1.16 \times 10^{4} \mathrm{~m}^{3}$ emerged from the breach in the middle of 
the retaining wall and was transported downstream. During the debris flow event on 21 June 2019, the prevention projects played a satisfactory role in controlling the debris flow disaster even though the flow magnitude exceeded the design standard.

In addition, studying the damage mechanism of mitigation structures is significant for effective debris flow mitigation. According to previous studies, the huge impact force of a debris flow can contribute significantly to the destruction of mitigation structures [34,77], and numerous impact models have been established [77-80]. Through comprehensive analysis of the existing debris flow impact models, a modified hydro-static model with a good prediction capability was proposed by Vagnon [77]. Therefore, the impact force of debris flow on the retaining wall was evaluated to study the damage mechanism by Ref. [77]:

$$
\begin{gathered}
P_{\text {peak }}=2.07 F_{r}{ }^{1.64} \gamma_{d f} g h_{d f} \\
F_{r}=V_{d f} / \sqrt{g h_{d f}}
\end{gathered}
$$

where $P_{\text {peak }}$ is the peak impact pressure $\left(\mathrm{kN} / \mathrm{m}^{2}\right) ; F_{r}$ is the Froude number; and $h_{d f}$ is the mean debris flow depth (m). Considering the large scale of the debris flow disaster on 21 June 2019, $\gamma_{d f}$ is taken as $1.9 \mathrm{t} / \mathrm{m}^{3}$ according to Table 4 . Based on field investigation, the average velocity of the debris flow $\left(V_{d f}\right)$ near the retaining wall was calculated through Equation (13), and related parameters are shown in Table 5.

Based on the related report, the designed resistance of the retaining wall is $51.34 \mathrm{KN} / \mathrm{m}^{2}$ [75], which is far below the calculated value of the peak impact pressure $\left(80.39 \mathrm{kN} / \mathrm{m}^{2}\right)$ in Table 5 . The debris flow impact force was greater than the resistance of the retaining wall, causing partial failure of the retaining wall on 21 June 2019. Thus, the resistance of the retaining wall should be increased during the design processes. In general, considerable attention should be given to the post-earthquake debris flow disaster in Zechawa Gully in the future, and it is necessary to repair the broken retaining wall with a greater design resistance and remove the debris flow material deposited behind the retaining wall to prepare for the next post-earthquake debris flow in the near future.

Table 5. Calculation results of the debris flow impact force on the retaining wall on 21 June 2019.

\begin{tabular}{ccccccc}
\hline$\gamma_{d f}\left(\mathbf{t} / \mathbf{m}^{3}\right)$ & $h_{f}(\mathbf{m})$ & $\boldsymbol{R}_{d f}(\mathbf{m})$ & $\boldsymbol{I}_{d f}$ & $n_{d f}$ & $\boldsymbol{F}_{r}$ & $\boldsymbol{P}_{\text {peak }}\left(\mathbf{k N} / \mathbf{m}^{2}\right)$ \\
\hline 1.9 & 1.55 & 1.11 & 0.19 & 0.1 & 1.20 & 80.39 \\
\hline
\end{tabular}

\section{Conclusions}

This study is intended to describe the debris flow events in Zechawa Gully, characterize the debris flow disaster, propose appropriate mitigation countermeasures and analyse the effectiveness of mitigation countermeasures that were already implemented in May 2019. Field investigations were conducted in a timely manner to determine the debris flow peak discharge, and the disaster characteristics and occurrence of debris flows in 2016 were analysed. The following conclusions can be drawn:

(1) In this study, the debris flow peak discharge was calculated using the rain-flood method, cross-section survey method, dam-breaking calculation method and maximum boulder size method. Based on our research, compared with previous results based on a single method, an accurate debris flow peak discharge can be obtained by comparing the results of each calculation method with each other, which increases the parameter accuracy for debris flow disaster prevention and risk assessment.

(2) According to the classification criterion of the debris flow scale, the debris flows in Zechawa Gully can be classified as small-scale events (with a total volume of debris flow material less than $1.0 \times 10^{4} \mathrm{~m}^{3}$ ) and medium-scale events (with a total volume of debris flow material between $1.0 \times 10^{4} \mathrm{~m}^{3}$ and $10 \times 10^{4} \mathrm{~m}^{3}$ ) [81]. The scale of the debris flow event on 4 August 2016 was 
equivalent to that of a debris flow with a 20-year return period. After the Ms 7.0 Jiuzhaigou earthquake, at least one debris flow with a scale less than that of a debris flow with a 10-year return period was triggered in September 2017, and a destructive debris flow with a scale greater than that of a debris flow with a 50-year return period was triggered in June 2019.

(3) The debris flow peak discharge on 4 August 2016 was amplified by the failure of the stone masonry check dam, causing widespread damage. Due to the disaster risk caused by dam breach incidents, an integrated strategy including blocking measures and deposit stopping measures should be adopted for debris flow mitigation.

(4) Based on the debris flow hazard characteristics of Zechawa Gully, optimized engineering countermeasures (including blocking measures and deposit stopping measures) with a design standard of a 50-year return period were proposed. Combined with the debris flow control principles for national parks, one satisfactorily concealed concrete check dam and one retaining wall out of view of tourists were constructed in Zechawa Gully in May 2019.

(5) On 21 June 2019, a post-earthquake debris flow was triggered by heavy rainfall, and the engineering countermeasure, including blocking and deposit stopping measures, were effective in mitigating the debris flow disaster even though the debris flow magnitude was greater than the design standard of the reconstructed engineering projects. More attention should be paid to the post-earthquake debris flow disaster in Zechawa Gully, and it is necessary to repair the broken retaining wall with greater design resistance and to remove the debris flow material deposited behind the retaining wall in a timely manner to prepare for upcoming post-earthquake debris flows in the near future.

\section{Notation}

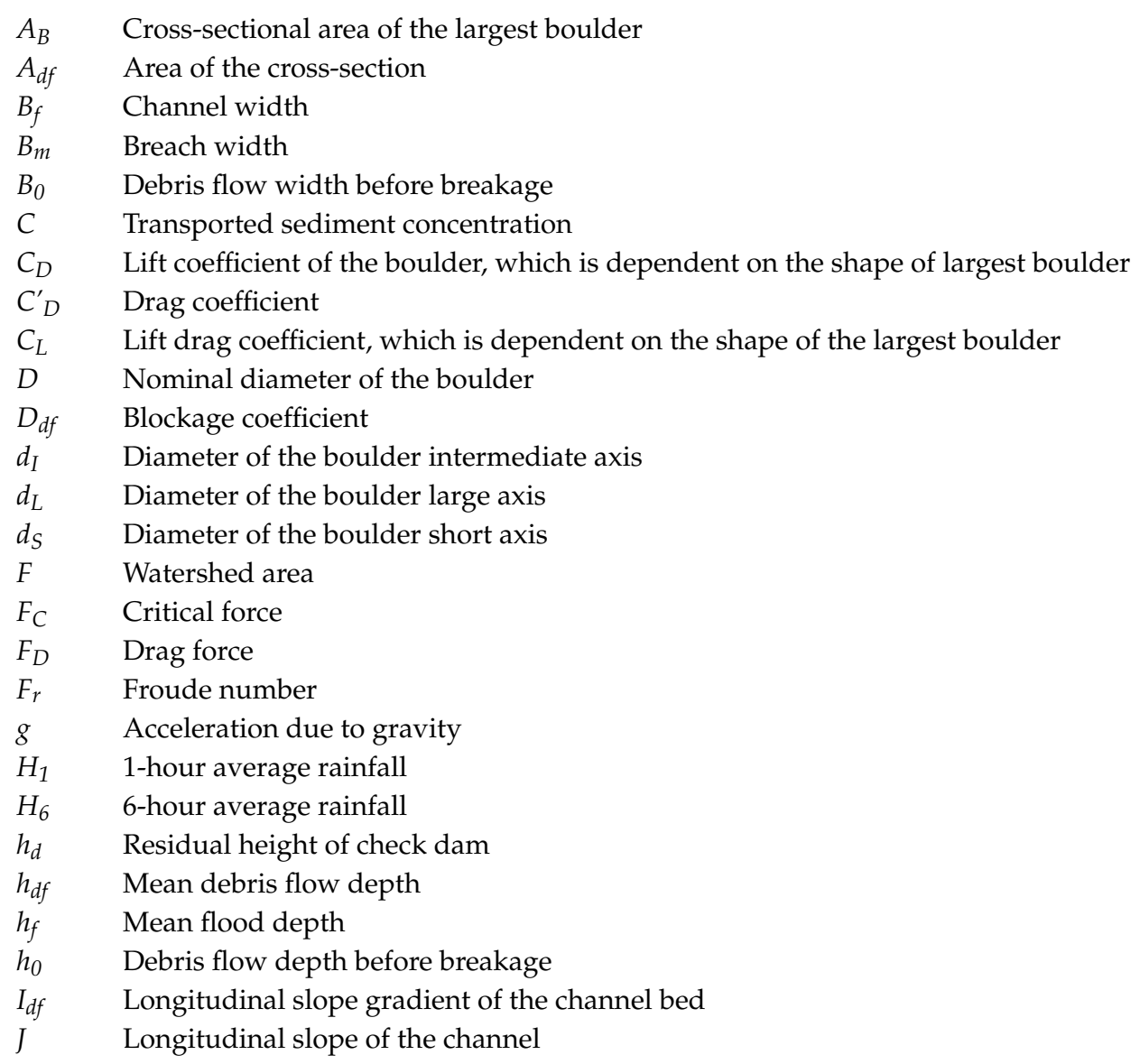


$K_{1} \quad$ Modulus coefficients corresponding to $H_{1}$ under different return periods

$K_{6} \quad$ Modulus coefficients corresponding to $H_{6}$ under different return periods.

$K_{p} \quad$ Modulus coefficient when the variation coefficient is equal to 0.23

$L \quad$ Main channel length

$L_{b} \quad$ Deposit length of the debris flow material behind the check dam

$M_{B} \quad$ Boulder mass

$M R_{D} \quad$ Drag turning arm

$M R_{L} \quad$ Lift turning arm

$m \quad$ Runoff confluence parameter

$n \quad$ Attenuation index of the rainstorm

$n_{d f} \quad$ Roughness coefficient of the debris flow gully

$n_{f} \quad$ Roughness coefficient of a mountain stream

$P_{\text {peak }} \quad$ Peak impact pressure

$Q_{d f} \quad$ Debris flow peak discharge

$Q_{f} \quad$ Flood peak discharge

$q_{f} \quad$ Unit width flux

$R_{d f} \quad$ Hydraulic radius of the debris flow

$S \quad$ Rainfall intensity

$T_{d f} \quad$ Duration time of the debris flow

$t \quad$ Runoff confluence time of the rainstorm

$t_{0} \quad$ Runoff confluence time of the rainstorm when $\phi$ equals 1.

$V_{\text {avg }} \quad$ Average velocity

$V_{d f} \quad$ Average velocity of the debris flow

$V_{f} \quad$ Critical velocity (bed velocity)

$W_{d f} \quad$ Total volume of the debris flow material

$w \quad$ Unit stream power

$\alpha \quad$ Original imbrication angle of the deposited boulder

$\beta \quad$ Bed slope angle

$\gamma_{d f} \quad$ Density of the debris flow

$\gamma_{s} \quad$ Density of the solid material

$\gamma_{w} \quad$ Density of the water

$\theta \quad$ Watershed characteristic parameter

$\mu \quad$ Shape coefficient, which is dependent on the shape of the largest boulder

$\rho_{b} \quad$ Maximum boulder density

$\rho_{f} \quad$ Fluid density

$\rho_{S} \quad$ Sediment density

$\tau \quad$ Bed shear stress

$\eta \quad$ Runoff yield parameter, which reflects the average infiltration intensity

$\phi \quad$ Runoff coefficient of the flood peak, which is related to the convergence of runoff

$\varphi_{d f} \quad$ Quasi-static friction angle

$\psi_{d f} \quad$ Amplification coefficient of the debris flow peak discharge

$\kappa \quad$ Influence factor that accounts for residual height

Author Contributions: X.-L.G. and K.-T.C. contributed to the conceptualization, methodology, analysis and manuscript writing of the study. X.-Q.C. proposed the main structure of this study and approved the final version. Y.Y. and J.-G.C. helped perform the analysis with constructive discussions. W.-Y.Z. and J.L. provided resources and participated in the field investigations. All authors have read and agreed to the published version of the manuscript.

Funding: This research was supported by the " 8.8 " Jiuzhaigou earthquake stricken area ecological disaster prevention and control of key scientific and technological support project of Land and Resources Department of Sichuan Province (Research on Prevention and Control Technology of Ecological Debris Flow Disasters, Grant No. KJ-2018-24), the National Natural Science Foundation of China (Grant No. 51709259), the Foundation for Young Scientists of the Institute of Mountain Hazards and Environment, CAS (Grant No. SDS-QN-1912), CAS "Light of West China" Program, the Youth Innovation Promotion Association CAS (2017426) and the Open Foundation of Key Laboratory of Mountain Hazards and Earth Surface Processes, CAS.

Conflicts of Interest: The authors declare no conflict of interest. 


\section{References}

1. Huggett, R. Fundamentals of Geomorphology; Routledge: London, UK, 2007. [CrossRef]

2. Jakob, M.; Hungr, O. Debris-Flow Hazards and Related Phenomena; Springer: Berlin, Germany, 2005.

3. Hungr, O.; Leroueil, S.; Picarelli, L. The Varnes classification of landslide types, an update. Landslides 2014, 11, 167-194. [CrossRef]

4. Chen, K.-T.; Chen, X.-Q.; Hu, G.-S.; Kuo, Y.-S.; Huang, Y.-R.; Shieh, C.-L. Dimensionless assessment method of landslide dam formation caused by tributary debris flow events. Geofluids 2019. [CrossRef]

5. Chen, K.-T.; Chen, X.-Q.; Niu, Z.-P.; Guo, X.-J. Early identification of river blocking induced by tributary debris flow based on dimensionless volume index. Landslides 2019. [CrossRef]

6. Chen, K.-T.; Lin, C.-H.; Chen, X.-Q.; Hu, G.-S.; Guo, X.-J.; Shieh, C.-L. An assessment method for debris flow dam formation in Taiwan. Earth Sci. Res. J. 2018, 22, 37-43. [CrossRef]

7. Ni, H.; Zheng, W.; Song, Z.; Xu, W. Catastrophic debris flows triggered by a 4 July 2013 rainfall in Shimian, SW China: Formation mechanism, disaster characteristics and the lessons learned. Landslides 2014, 11, 909-921. [CrossRef]

8. Tang, C.; Zhu, J.; Ding, J.; Cui, X.F.; Chen, L.; Zhang, J.S. Catastrophic debris flows triggered by a 14 August 2010 rainfall at the epicenter of the Wenchuan earthquake. Landslides 2011, 8, 485-497. [CrossRef]

9. Yu, B.; Ma, Y.; Wu, Y. Case study of a giant debris flow in the Wenjia Gully, Sichuan Province, China. Nat. Hazards 2012, 65, 835-849. [CrossRef]

10. Chen, M.-L.; Liu, X.-N.; Wang, X.-K.; Zhao, T.; Zhou, J.-W. Contribution of Excessive Supply of Solid Material to a Runoff-Generated Debris Flow during Its Routing Along a Gully and Its Impact on the Downstream Village with Blockage Effects. Water 2019, 11, 169. [CrossRef]

11. Chen, X.; Cui, P.; You, Y.; Chen, J.; Li, D. Engineering measures for debris flow hazard mitigation in the Wenchuan earthquake area. Eng. Geol. 2015, 194, 73-85. [CrossRef]

12. Ni, H.; Tang, C.; Zheng, W.; Xu, R.; Tian, K.; Xu, W. An overview of formation mechanism and disaster characteristics of post-seismic debris flows triggered by subsequent rainstorms in Wenchuan earthquake extremely stricken areas. Acta Geol. Sin. 2014, 88, 1310-1328. [CrossRef]

13. Ni, H.Y.; Zheng, W.M.; Tie, Y.B.; Su, P.C.; Tang, Y.Q.; Xu, R.G.; Wang, D.W.; Chen, X.Y. Formation and characteristics of post-earthquake debris flow: A case study from Wenjia gully in Mianzhu, Sichuan, SW China. Nat. Hazards 2011, 61, 317-335. [CrossRef]

14. Yu, B.; Wu, Y.; Chu, S. Preliminary study of the effect of earthquakes on the rainfall threshold of debris flows. Eng. Geol. 2014, 182, 130-135. [CrossRef]

15. Guo, X.; Cui, P.; Li, Y.; Zhang, J.; Ma, L.; Mahoney, W.B. Spatial features of debris flows and their rainfall thresholds in the Wenchuan earthquake-affected area. Landslides 2016, 13, 1215-1229. [CrossRef]

16. Guo, X.; Cui, P.; Marchi, L.; Ge, Y. Characteristics of rainfall responsible for debris flows in Wenchuan earthquake area. Environ. Earth Sci. 2017, 76, 596. [CrossRef]

17. Li, T.-T.; Huang, R.-Q.; Pei, X.-J. Variability in rainfall threshold for debris flow after Wenchuan earthquake in Gaochuan River watershed, Southwest China. Nat. Hazards 2016, 82, 1967-1980. [CrossRef]

18. Ma, C.; Wang, Y.; Hu, K.; Du, C.; Yang, W. Rainfall intensity-duration threshold and erosion competence of debris flows in four areas affected by the 2008 Wenchuan earthquake. Geomorphology 2017, 282, 85-95. [CrossRef]

19. Shieh, C.L.; Chen, Y.S.; Tsai, Y.J.; Wu, J.H. Variability in rainfall threshold for debris flow after the Chi-Chi earthquake in central Taiwan, China. Int. J. Sediment Res. 2009, 24, 177-188. [CrossRef]

20. Zhou, W.; Tang, C. Rainfall thresholds for debris flow initiation in the Wenchuan earthquake-stricken area, Southwestern China. Landslides 2014, 11, 877-887. [CrossRef]

21. Tang, C.; van Asch, T.W.J.; Chang, M.; Chen, G.Q.; Zhao, X.H.; Huang, X.C. Catastrophic debris flows on 13 August 2010 in the Qingping area, Southwestern China: The combined effects of a strong earthquake and subsequent rainstorms. Geomorphology 2012, 139-140, 559-576. [CrossRef]

22. Zeng, Q.L.; Yue, Z.Q.; Yang, Z.F.; Zhang, X.J. A case study of long-term field performance of check-dams in mitigation of soil erosion in Jiangjia stream, China. Environ. Geol. 2008, 58, 897-911. [CrossRef]

23. Peng, C.; Yongming, L. Debris-Flow Treatment: The Integration of Botanical and Geotechnical Methods. J. Resour. Ecol. 2013, 4, 097-104. [CrossRef] 
24. DeWolfe, V.G.; Santi, P.M.; Ey, J.; Gartner, J.E. Effective mitigation of debris flows at Lemon Dam, La Plata County, Colorado. Geomorphology 2008, 96, 366-377. [CrossRef]

25. Piton, G.; Carladous, S.; Recking, A.; Tacnet, J.M.; Liébault, F.; Kuss, D.; Quefféléan, Y.; Marco, O. Why do we build check dams in Alpine streams? An historical perspective from the French experience. Earth Surf. Process. Landf. 2016, 42, 91-108. [CrossRef]

26. Cucchiaro, S.; Cavalli, M.; Vericat, D.; Crema, S.; Llena, M.; Beinat, A.; Marchi, L.; Cazorzi, F. Geomorphic effectiveness of check dams in a debris-flow catchment using multi-temporal topographic surveys. CATENA 2019, 174, 73-83. [CrossRef]

27. Cucchiaro, S.; Cazorzi, F.; Marchi, L.; Crema, S.; Beinat, A.; Cavalli, M. Multi-temporal analysis of the role of check dams in a debris-flow channel: Linking structural and functional connectivity. Geomorphology 2019. [CrossRef]

28. Piton, G.; Recking, A. Design of Sediment Traps with Open Check Dams. I: Hydraulic and Deposition Processes. J. Hydraul. Eng. 2016, 142. [CrossRef]

29. Bernard, M.; Boreggio, M.; Degetto, M.; Gregoretti, C. Model-based approach for design and performance evaluation of works controlling stony debris flow with an application to a case study at Rovina di Cancia (Venetian Dolomites, Northeast Italy). Sci. Total Environ. 2019. [CrossRef]

30. Albaba, A.; Lambert, S.; Kneib, F.; Chareyre, B.; Nicot, F. DEM Modeling of a Flexible Barrier Impacted by a Dry Granular Flow. Rock Mech. Rock Eng. 2017, 50, 3029-3048. [CrossRef]

31. Leonardi, A.; Wittel, F.K.; Mendoza, M.; Vetter, R.; Herrmann, H.J. Particle-Fluid-Structure Interaction for Debris Flow Impact on Flexible Barriers. Comput.-Aided Civ. Infrastruct. Eng. 2015, 31, 323-333. [CrossRef]

32. Zhu, Z.-H.; Yin, J.-H.; Qin, J.-Q.; Tan, D.-Y. A new discrete element model for simulating a flexible ring net barrier under rockfall impact comparing with large-scale physical model test data. Comput. Geotech. 2019, 116, 103208. [CrossRef]

33. Albaba, A.; Lambert, S.; Nicot, F.; Chareyre, B. Relation between microstructure and loading applied by a granular flow to a rigid wall using DEM modeling. Granul. Matter 2015, 17, 603-616. [CrossRef]

34. Wang, G.L. Lessons learned from protective measures associated with the 2010 Zhouqu debris flow disaster in China. Nat. Hazards 2013, 69, 1835-1847. [CrossRef]

35. Liu, F.Z.; Xu, Q.; Dong, X.J.; Yu, B.; Frost, J.D.; Li, H.J. Design and performance of a novel multi-function debris flow mitigation system in Wenjia Gully, Sichuan. Landslides 2017, 14, 2089-2104. [CrossRef]

36. Chen, X.-Q.; Chen, J.-G.; Cui, P.; You, Y.; Hu, K.-H.; Yang, Z.-J.; Zhang, W.-F.; Li, X.-P.; Wu, Y. Assessment of prospective hazards resulting from the 2017 earthquake at the world heritage site Jiuzhaigou Valley, Sichuan, China. J. Mt. Sci. 2018, 15, 779-792. [CrossRef]

37. Hu, X.; Hu, K.; Tang, J.; You, Y.; Wu, C. Assessment of debris-flow potential dangers in the Jiuzhaigou Valley following the August 8, 2017, Jiuzhaigou earthquake, Western China. Eng. Geol. 2019, 256, 57-66. [CrossRef]

38. Zhao, B.; Wang, Y.S.; Luo, Y.H.; Li, J.; Zhang, X.; Shen, T. Landslides and dam damage resulting from the Jiuzhaigou earthquake (8 August 2017), Sichuan, China. R. Soc. Open Sci. 2018, 5, 171418. [CrossRef]

39. Chen, S.F.; Wilson, C.; Deng, Q.D.; Zhao, X.L.; Zhi, L.L. Active faulting and block movement associated with large earthquakes in the Min Shan and Longmen Mountains, Northeastern Tibetan Plateau. J. Geophys. Res. Solid Earth 1994, 99, 24025-24038. [CrossRef]

40. Yin, A.; Harrison, T.M. Geologic evolution of the Himalayan-Tibetan orogen. Ann. Rev. Earth Planet. Sci. 2000, 28, 211-280. [CrossRef]

41. Zhao, D.; Qu, C.; Shan, X.; Gong, W.; Zhang, Y.; Zhang, G. InSAR and GPS derived coseismic deformation and fault model of the 2017 Ms7.0 Jiuzhaigou earthquake in the Northeast Bayanhar block. Tectonophysics 2018, 726, 86-99. [CrossRef]

42. Liu, Z.; Tian, X.; Gao, R.; Wang, G.; Wu, Z.; Zhou, B.; Tan, P.; Nie, S.; Yu, G.; Zhu, G.; et al. New images of the crustal structure beneath eastern Tibet from a high-density seismic array. Earth Planet. Sci. Lett. 2017, 480, 33-41. [CrossRef]

43. Ren, J.; Xu, X.; Yeats, R.S.; Zhang, S. Millennial slip rates of the Tazang fault, the Eastern termination of Kunlun fault: Implications for strain partitioning in eastern Tibet. Tectonophysics 2013, 608, 1180-1200. [CrossRef]

44. Zhao, X.L.; Deng, Q.D.; Chen, S.F. Tectonic geomorphology of the Minshan uplift in Western Sichuan, Southwestern China. Seismol. Geol. 1994, 16, 429-439. (In Chinese) 
45. Zhou, R.; Li, Y.; Densmore, A.L.; Ellis, M.A.; He, Y.; Wang, F.; Li, X. Active tectonics of the eastern margin of the Tibet Plateau. J. Mineral. Petrol. 2006, 26, 40-51. (In Chinese) [CrossRef]

46. Fan, X.; Scaringi, G.; Xu, Q.; Zhan, W.; Dai, L.; Li, Y.; Pei, X.; Yang, Q.; Huang, R. Coseismic landslides triggered by the 8th August 2017 M s 7.0 Jiuzhaigou earthquake (Sichuan, China): Factors controlling their spatial distribution and implications for the seismogenic blind fault identification. Landslides 2018, 15, 967-983. [CrossRef]

47. Nie, Z.; Wang, D.-J.; Jia, Z.; Yu, P.; Li, L. Fault model of the 2017 Jiuzhaigou Mw 6.5 earthquake estimated from coseismic deformation observed using global positioning system and interferometric synthetic aperture radar data. Earth Planets Space 2018, 70, 55. [CrossRef]

48. Xie, Z.; Zheng, Y.; Yao, H.; Fang, L.; Zhang, Y.; Liu, C.; Wang, M.; Shan, B.; Zhang, H.; Ren, J.; et al. Preliminary analysis on the source properties and seismogenic structure of the 2017 Ms7.0 Jiuzhaigou earthquake. Sci. China Earth Sci. 2018, 61, 339-352. [CrossRef]

49. Cui, P.; Liu, S.Q.; Tang, B.X.; Chen, X.; Zhang, X. Debris Flow Study and Prevention in National Park; Science Press: Beijing, China, 2005; pp. 90-92. (In Chinese)

50. Jiang, T.; Yang, J.C.; Peng, S.E.; Wang, S.F.; Zhou, Y.; Qi, Y.L.; Wei, J.G. Construction Drawing Design Report for the Control Projects of Zechawa and Xiajijie Debris Flow Disasters in Jiuzhaigou Valley; Nuclear Industry Southwest Survey and Design Institute Co., Ltd.: Chengdu, China, 2009.

51. Sun, H.; You, Y.; Liu, J.-F. Experimental study on characteristics of trapping and regulating sediment with an open-type check dam in debris flow hazard mitigation. J. Mt. Sci. 2018, 15, 2001-2012. [CrossRef]

52. You, Y.; Liu, J.F.; Chen, X.C. Debris flow and its characteristics of Subao River in Beichuan county after 5.12 Wenchuan earthquake. J. Mt. Sci. 2010, 28, 358-366. (In Chinese)

53. Liu, J.; You, Y.; Chen, X.; Liu, J.; Chen, X. Characteristics and hazard prediction of large-scale debris flow of Xiaojia Gully in Yingxiu Town, Sichuan Province, China. Eng. Geol. 2014, 180, 55-67. [CrossRef]

54. Zhou, B.F.; Li, D.J.; Luo, D.F.; Lv, R.R.; Yang, Q.X. Guide to Prevention of Debris Flow; Science Press: Beijing, China, 1991; pp. 80-95. (In Chinese)

55. Tang, C.; Rengers, N.V.; van Asch, T.W.; Yang, Y.; Wang, G. Triggering conditions and depositional characteristics of a disastrous debris flow event in Zhouqu city, Gansu Province, Northwestern China. Nat. Hazards Earth Syst. Sci. 2011, 11, 2903-2912. [CrossRef]

56. Xiong, M.Q.; Meng, X.M.; Wang, S.Y.; Guo, P.; Li, Y.J.; Chen, G.; Qing, F.; Cui, Z.J.; Zhao, Y. Effectiveness of debris flow mitigation strategies in mountainous regions. Prog. Phys. Geogr. 2016, 40, 768-793. [CrossRef]

57. Costa, J.E. Paleohydraulic reconstruction of flash-flood peaks from boulder deposits in the Colorado front range. Geol. Soc. Am. Bull. 1983, 94, 986-1004. [CrossRef]

58. Lanzoni, S.; Gregoretti, C.; Stancanelli, L.M. Coarse-grained debris flow dynamics on erodible beds. J. Geophys. Res. Earth Surf. 2017, 122, 592-614. [CrossRef]

59. Chanson, H. The Hydraulics of Open Channel Flow: An Introduction, 2rd ed.; Elsevier Butterworth-Heinemann: Oxford, UK, 2004.

60. Subramanya, K. Flow in Open Channels, 3rd ed.; Elsevier Butterworth-Heinemann: Oxford, UK, 2009.

61. Ministry of Water Resources of the People's Republic of China (MWR). Technique Guideline for Emergency Disposal of Landslide Lake; SL451-2009; Standards Press of China: Beijing, China, 2009; pp. 22-25. (In Chinese)

62. Dai, R.Y.; Wang, Q. Research on the maximum discharge of dam-breaking. J. Hydraul. Eng. 1983, 2, 15-23. (In Chinese)

63. Takahashi, T. Debris Flow Mechanics, Prediction and Countermeasures; Taylor \& Francis Group: London, UK, 2007; pp. 45-47. [CrossRef]

64. Schoklitsch, A. Der geschiebetrieb und die geschiebefracht. Wasserkraft Wasserwirtschaft 1934, $29,37-43$.

65. Du, C.; Yao, L.-K.; Shakya, S.; Li, L.-G.; Sun, X.-D. Damming of large river by debris flow: Dynamic process and particle composition. J. Mt. Sci. 2014, 11, 634-643. [CrossRef]

66. Helley, E.J. Field Measurement of the Initiation of Large Bed Particle Motion in Blue Creek Near Kalmath, California; US Geological Survey Professional Paper; United States Government Printing Office: Washington, DC, USA, 1969.

67. Williams, G.P. Paleohydrological methods and some examples from Swedish fluvial environments: I cobble and boulder deposits. Geogr. Ann. Ser. A Phys. Geogr. 1983, 65, 227-243. [CrossRef]

68. Clarke, A.O. Estimating probable maximum floods in the Upper Santa Ana Basin, Southern California, from stream boulder size. Environ. Eng. Geosci. 1996, 2, 165-182. [CrossRef] 
69. Zhao, Z.X.; He, J.J. Hydraulics; Tsinghua University Press: Beijing, China, 2010; pp. 176-177. (In Chinese)

70. China Association of Geological Hazard Prevention (CAGHP). Specification of Design for Debris Flow Prevention; T/CAGHP 021-2018; China University of Geosciences Press: Wuhan, China, 2018; pp. 3-6. (In Chinese)

71. Rickenmann, D. Hyperconcentrated Flow and Sediment Transport at Steep Slopes. J. Hydraul. Eng. 1991, 117, 1419-1439. [CrossRef]

72. You, Y.; Chen, X.; Liu, J. 8.13" extra large debris flow disaster in Wenjia gully of Qingping Township, Mianzhu, Sichuan Province. J. Catastrophol. 2011, 26, 68-72. (In Chinese)

73. Cui, P.; Zhou, G.G.D.; Zhu, X.H.; Zhang, J.Q. Scale amplification of natural debris flows caused by cascading landslide dam failures. Geomorphology 2013, 182, 173-189. [CrossRef]

74. Zhou, G.G.D.; Cui, P.; Chen, H.Y.; Zhu, X.H.; Tang, J.B.; Sun, Q.C. Experimental study on cascading landslide dam failures by upstream flows. Landslides 2012, 10, 633-643. [CrossRef]

75. Chen, X.Q.; Chen, X.Z.; Zhang, W.F.; Chen, K.T.; Yang, D.X.; Hu, K.; Gong, X.L.; Si, G.W.; Xiong, Z. Investigation Report for the Control of Zechawa Debris Flow Disaster in Jiuzhaigou Valley, Jiuzhaigou County; Institute of Mountain Hazards and Environment, Chinese Academy of Sciences: Chengdu, China, 2017. (In Chinese)

76. Cui, P.; Liu, S.; Tang, B.; Chen, X. Debris flow prevention pattern in national parks-taking the world natural heritage Jiuzhaigou as an example. Sci. China 2003, 46, 1-11. [CrossRef]

77. Vagnon, F. Design of active debris flow mitigation measures: A comprehensive analysis of existing impact models. Landslides 2019. [CrossRef]

78. Zhang, S.A. Comprehensive Approach to the Observation and Prevention of Debris Flows in China. Nat. Hazards 1993, 7, 1-23. [CrossRef]

79. Cui, P.; Zeng, C.; Lei, Y. Experimental analysis on the impact force of viscous debris flow. Earth Surf. Process. Landf. 2015, 40, 1644-1655. [CrossRef]

80. Vagnon, F.; Segalini, A. Debris flow impact estimation on a rigid barrier. Nat. Hazards Earth Syst. Sci. 2016, 16, 1691-1697. [CrossRef]

81. Ministry of Land and Resources of the People's Republic of China (MLR). Specification of Geological Investigation for Debris Flow Stabilization; DZ/T0220-2006; Standards Press of China: Beijing, China, 2006; pp. 2-3. (In Chinese)

(C) 2020 by the authors. Licensee MDPI, Basel, Switzerland. This article is an open access article distributed under the terms and conditions of the Creative Commons Attribution (CC BY) license (http://creativecommons.org/licenses/by/4.0/). 